\title{
Nafta and Mexico's Economic Growth from a Gender Perspective
}

\author{
Luis Rene Caceres ${ }^{1}$ \\ ${ }^{1}$ Independent Researcher, El Salvador \\ Correspondence: Luis Rene Caceres, 5456 Paseo General Escalon, San Salvador, El Salvador.
}

Received: July 17, 2021

Accepted: November 26, 2021

Online Published: November 28, 2021

doi:10.5539/ijef.v13n12p90

URL: https://doi.org/10.5539/ijef.v13n12p90

\begin{abstract}
This paper investigates the dynamics of Mexico's economy after the signing of the NAFTA treaty. It is reported that Mexico, the United States and Canada have experienced low rates of economic growth as a result of the deindustrialization processes they have undergone, which has been a consequence of the tariff reductions. Tariff reduction has also affected employment, especially female industrial employment, with adverse consequences on domestic savings, trade balance and economic growth. Additional analysis is related to cointegration tests of the employment ratios, as well as to the existence of principal components among the three countries' employment to population ratios. The paper investigates the effects of declining employment to population ratios in the three countries, reporting that in Mexico female employment has increased to compensate the declining tendencies of labor productivity and male employment ratio. The paper ends with a proposal regarding the launching of the North American Social and Dignity Pact.
\end{abstract}

JEL: F15, F16, F63, I25.

Keywords: deindustrialization, employment ratios, economic integration, cointegration, principal components, domestic savings, gender

\section{Introduction}

The signing of the North American Free Trade Agreement in 1994 by the governments of Mexico, the United States and Canada was celebrated in political, academic and business circles as a safe bet to promote the development of the first country, as a result of greater efficiency resulting from competition and the use of comparative advantages. The United States had established a free trade agreement with Canada in 1989, while Mexico had joined the World Trade Organization in 1986 and had undertaken trade liberalization measures, reforms that were far from the ambitious measures included in NAFTA.

For Mexico, the initial results were positive, especially in relation to the growth of exports to the United States, which increased from 66.47 billion dollars in 1995 to 238.68 billion in 2010 to reach 370.78 billion in 2019, when Mexico occupied the position of first exporter to the US. This has been accompanied by significant increases in employment in maquila activities, located mainly in areas close to the US border. However, economic growth has not experienced dynamism, showing an average value of 2.60 percent in the 1996-2019 period, and 2.08 percent between 2000 and 2019, placing the Mexican economy among the least dynamic ones of the Latin America countries, which contrasts with the high economic growth rates shown in the 1950s, 1960s and 1970s, when the import substitution model was in effect. It is observed in Figure 1 that the growth rate of the Mexican economy shows a tendency to fall that has not been reversed by NAFTA.

MXGROWTH

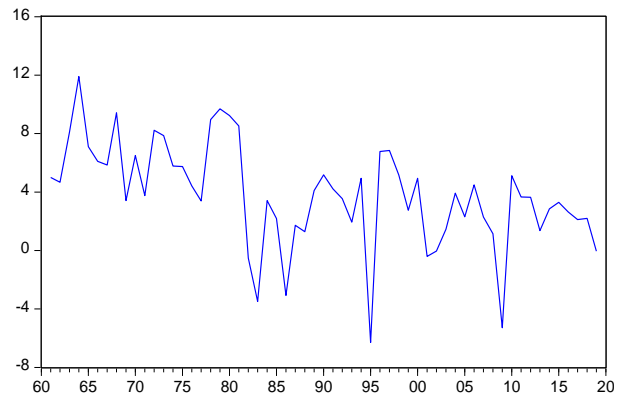

Figure 1. Mexico's annual rates of economic growth

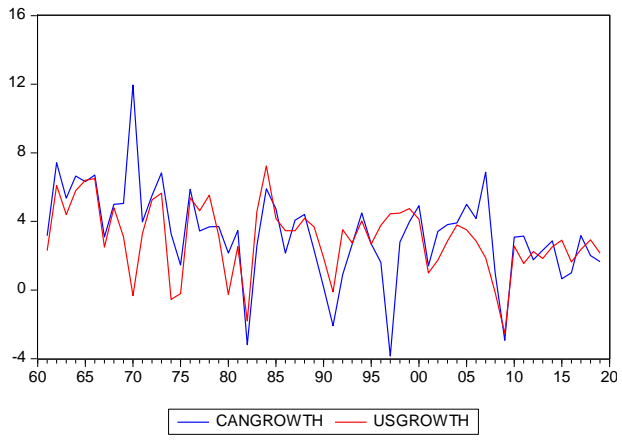

Figure 2. Growth rates of the US and Canadian economies 
The economic growth rates of the United States and Canada also show declining trends, as seen in Figure 2.

Figures 1 and 2 show that in the three countries economic dynamism has been elusive after the mid-1980s, which makes NAFTA an integrated continental area characterized by economic stagnation tendencies. This paper investigates the causes of the slow growth of the Mexican economy in light of NAFTA. It is based on the fact that as a consequence of trade liberalization, Mexico reduced import tariffs, measured as the simple average of all products, from 14.02 percent in 1995 to 1.21 percent in 2019, thus giving rise to a deep deindustrialization, which is manifested in the drop of the share of the value added of the manufacturing sector in GDP from 20.20 in 1995 to 15.35 percent in 2011, to recover to 17.33 percent in 2019. The United States and Canada underwent more severe deindustrialization processes than that experienced by Mexico. These results place NAFTA as a pact for the inadvertent destruction of the manufacturing sectors.

The following section presents a description of the data and its statistical properties. The deindustrialization process and its repercussions on industrial employment, particularly female employment, are analyzed next. The following section analyzes the implications of female job losses on household savings, the trade account deficit, and economic growth. The next section presents an analysis of the role of demography in Mexico's economic growth, which is followed by the proposal of a North American Social and Dignity Compact. The paper ends with a series of conclusions.

\section{The Data and Its Statistical Properties}

The data source for all variables is the World Bank's World Development Indicators. The variables were subjected to unit root tests, finding that all were integrated of order 1 at the level of five percent, except Mexico's economic growth rate, MXGrowth, which turned out to be stationary at the level of one percent. The mean values and standard deviations of the variables are shown in Table 1.

Table 1. Average values and standard deviations of the variables, 1996-2019

\begin{tabular}{lcc}
\hline Variable & Average value & Standard deviation \\
\hline MX Growth & 2.6066 & 2.5947 \\
USGrowth & & \\
CAN Growth & & \\
MX Manu & 16.9886 & 1.5602 \\
US Manu & 13.0537 & 1.5041 \\
CAN Manu & 12.9798 & 2.9734 \\
MX Ratioindustrial & 0.6264 & 0.0830 \\
US Ratioindustrial & 0.3177 & 0.0291 \\
CAN Ratioindustrial & 0.3106 & 0.0291 \\
MX Ratio servicios & 1.5310 & 0.0287 \\
US Ratio services & 1.3393 & 0.0209 \\
CAN Ratio service & 1.3511 & 0.0156 \\
MX Tariff & 6.3013 & 5.1350 \\
US Tariff & 1.9226 & 0.4274 \\
CAN Tariff & 4.2252 & 1.4274 \\
\hline
\end{tabular}

Since the variables are integrated of order one, the estimations of the equations were carried out with the Fully Modified Least Squares methodology, developed by Phillips and Hansen (1990).

\section{The Growth of the Mexican Economy}

The entry into force of NAFTA did not reverse the declining trends of the economic growth rates of the member countries; in the case of Mexico, this is striking given the dynamism experienced by its exports to the United States, as shown in Figure 3. 


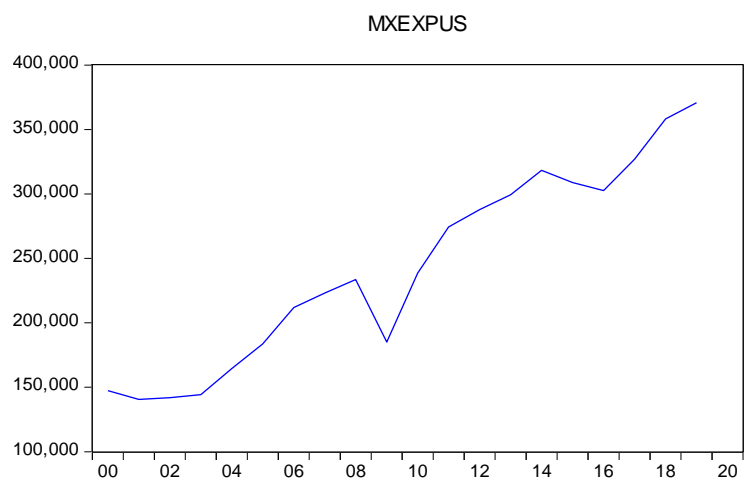

Figure 3. Exports from Mexico to the US, millions of US dollars

To appreciate the relationship of the growth of the Mexican economy, MXGrowth, in the period 1996-2019, with the economic growth of the United States and Canada, countries that are its first and second trading partners in terms of the value of exports, an equation was estimated, expressing the annual economic growth of Mexico in terms of the growth of the US economy, USGrowth, and a qualitative variable, MXcuali, which takes the value of 1 in the years that the Mexican economy experienced contractions, with the following results (Note 1):

MXGrowth $=0.7151-2.5162 \mathrm{MXcuali}+0.9038$ USGrowth

$$
\text { (1.08) (2.52) (4.26) }
$$

$\mathrm{R}$ squared $=0.73$

It is observed that the coefficient of USGrowth is positive and significant and the equation explains about three quarters of the variance of MXGrowth.

Another equation was estimated by introducing the growth rate of the Canadian economy, CANGrowth, with the following result:

MXGrowth $=1.0914-3.0128 \mathrm{MXCuali}+0.9423$ USGrowth -0.1734 CANGrowth

R squared $=0.88$

In this equation the coefficient of CANGrowth is negative but not significant.

A third equation was estimated including in the previous one the growth of the economy of China, CHINAGrowth, a country that occupies the third place in the value of Mexican exports:

MXGrowth $=-1.4148-2.8871 \mathrm{MXCuali}+1.0560$ USGrowth -0.2788 CANGrowth +0.2647 CHINAGrowth

$$
\text { (1.20) (4.01) (6.60) (2.62) }
$$

$\mathrm{R}$ squared $=0.78$

The value of the coefficient of USGrowth, (1.0560), is of the same order of magnitude as the value of 1.5 obtained by Swinton and Bayoumi (2008) using a VAR model estimated with quarterly data of the growth rates of Mexico and the United States. Arora and Vamvakidis (2004) reported that half of Mexico's economic growth in the second half of the 1990s originated in the growth of the NAFTA partners. These results underscore the importance of US economic growth to boost the Mexican economy. The negative value of the Canadian coefficient should be seen in light of the results obtained by Carderelli and Kose (2004) that the growth of the Canadian economy is determined, to a greater degree than that of the United States, by country-specific variables, which reflect its peculiar economic structure.

It should be noted that the magnitude of China's economic growth coefficient (0.2647) is a quarter of the coefficient of the United States (1.05), despite the fact that Mexican exports to China only reached 7.13 billion in 2019, (that year exports to Canada they were 14.32 billion).

\section{Deindustrialization in the Member Countries of NAFTA}

This section investigates the reasons for the low growth rates of the Mexican economy, based on the role that deindustrialization has played in its stagnation. The analysis takes into account the performance of the other member countries of NAFTA, which have also experienced contractions in the participation of the value added of the manufacturing sector in GDP, and low rates of economic growth, thus giving rise to a "stagnation triangle". 
Figure 4 shows that the participation of the manufacturing sector in the GDP of the three countries shows persistent falls in the period under study, changing in the case of Mexico from 19 percent in 1990 to 15.56 in 2009, recovering thereafter to reach 17.33 per cent in 2019. The United States and Canada also show contractions in the manufacturing sector, with respective values of 11.2 and 9.93 percent in 2019. The particularity and severity of these processes is appreciated when considering that Tregenna (2016) found, in an analysis of the manufacturing industry's share of GDP of a broad sample of countries, that at the global level, a 10 percent share of the manufacturing sector in GDP is typical of countries with the lowest levels of per capita GDP in the world. In other words, after deindustrialization, the United States and Canada have shares of manufacturing that reflect values like those of the most underdeveloped countries in the world.

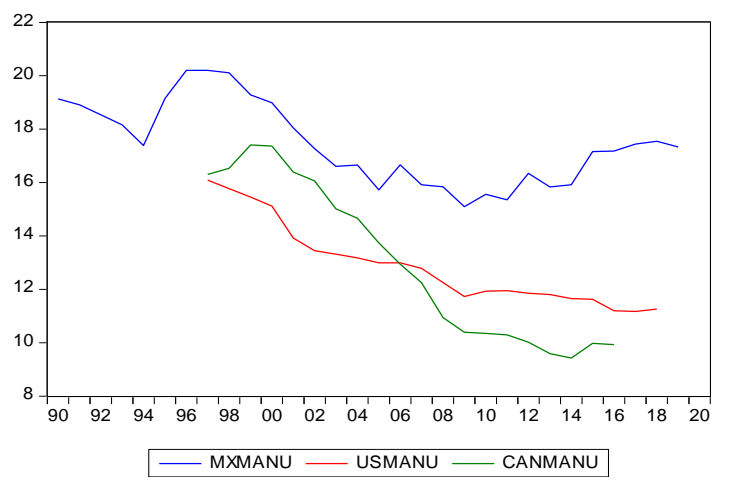

Figure 4. Added value of the manufacturing sectors in GDP, percentages

The negative repercussions of deindustrialization can be seen in the results presented by Kaldor (1966), and replicated by several authors, that the manufacturing sector is the main engine of economic growth. Several authors have reported that the cause of deindustrialization lies in foreign trade. Singh's precursor work (1977) showed that the tendency to stagnation of the British economy was explained by the reduction of the importance of the manufacturing sector in GDP, given the difficulty of competing with imports of manufactured goods. Rowthorn and Ramaswamy (1988) reported for the case of 18 developed countries that their deindustrialization was explained by imports of manufactured goods from developing countries; a similar conclusion was reported by Sarger (1997) for the case of the OECD countries.

Also, in the case of the OECD countries, Tregena (2016) reported that the economic liberalization policies adopted by these countries at the beginning of the decade of the 1990s, led to the drop in the share of the added value of the manufacturing sector in GDP by 10 percentage points, and to the loss of industrial employment by 50 percent of total employment.

With a view to investigating the degree to which deindustrialization is due to the role of imports in displacing the manufacturing sector in NAFTA member countries, the following Figures present the relationships between their imports as a percentage of GDP and the share of value added that their manufacturing sector represents in their GDP. It is observed that negative relationships exist in Mexico and the United States, (Figures 5 and 6 respectively), and it is very marked in the second country, so the deindustrialization of these countries can legitimately be associated with the increase in imports as a percentage of GDP.

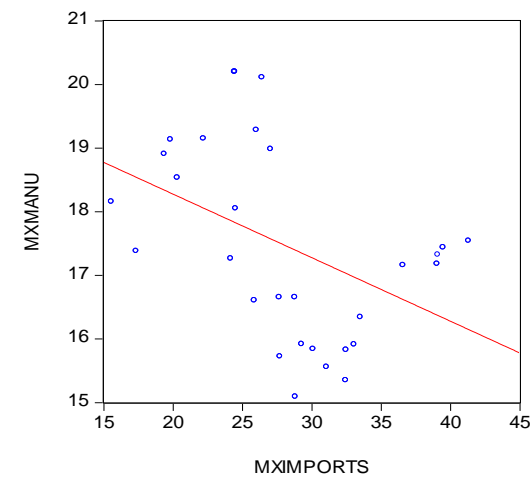

Figure 5. Mexico: Imports as a percentage of

GDP (MXImports), and a percentage of manufacturing sector (MXManu)

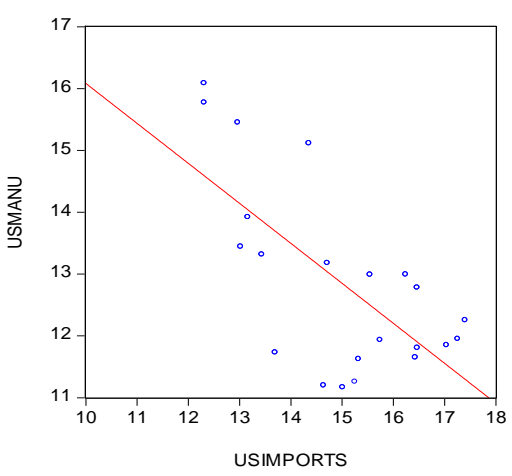

Figure 6. United States: Imports as percentages of GDP (USImports), and percentage of manufacturing sector, (USManu), both as percentages of GDP 
In Canada (Figure 7) the opposite behavior is observed, since its increase in imports leads to the growth of the manufacturing sector; this reflects the fact that the industry in this country depends on the import of parts and components from the United States for assembly in Canada, an issue that is analyzed by Cardarelli and Kose (2004).

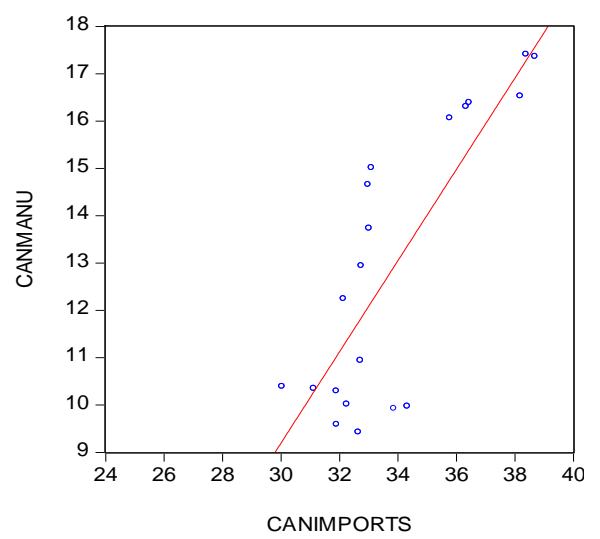

Figure 7. Canada: Imports and manufacturing sector, both as percentages of GDP

The literature cited above shows evidence of the perverse role of economic openness; recent evidence has been reported by Caceres (2017) for El Salvador, as well as for Mexico and the Central American countries (Caceres, 2021a). Cárdenas, de Hoyos and Szekely (2015) reported results that indicated that the openness of Latin American economies is a determinant of the percentage of the young population that is in the NEET situation, that is, that does not study or work.

To highlight the role of foreign trade liberalization as a cause of deindustrialization, Figure 8 shows that in Mexico in the period 1996-2018, the reduction in the weighted tariff on imports was accompanied by the fall in the percentage of manufacturing industry in the GDP. Similar relationships are observed in the cases of the United States and Canada with data from the same period, in Figures 9 and 10 respectively. From these Figures it can be deduced that the starting point of the trends towards economic stagnation has been trade liberalization.

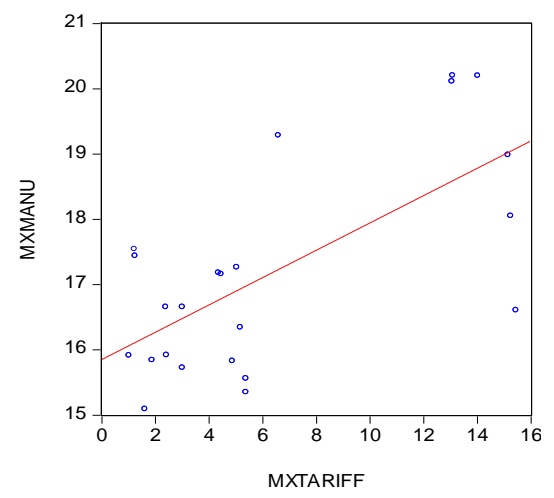

Figure 8. Tariff and added value of the manufacturing sector in Mexico

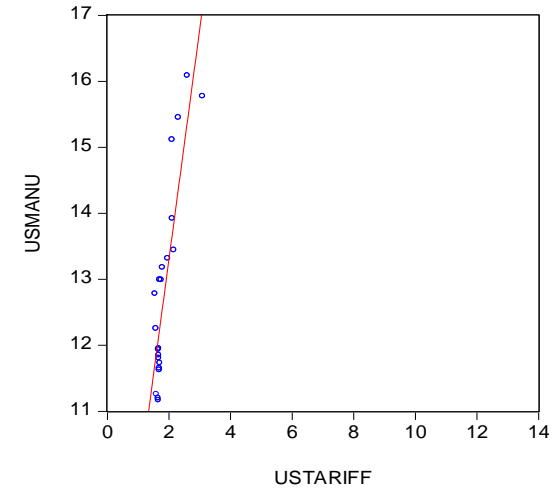

Figure 9. Tariff and added value of the manufacturing sector in the United States

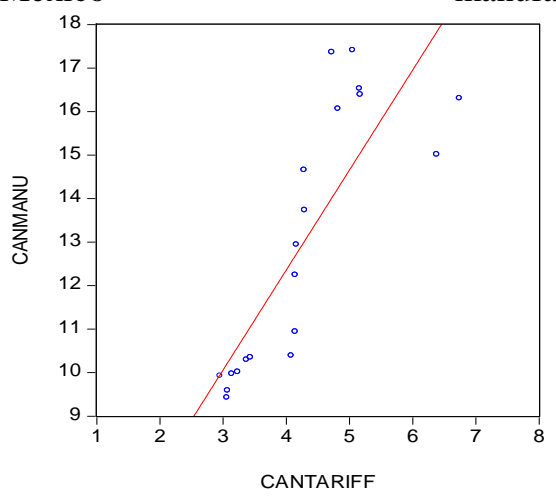

Figure 10. Tariff and added value of the manufacturing sector in Canada 
The growth of the share of imports in GDP cannot be attributed exclusively to the trade liberalization resulting from NAFTA, except in Mexico, since in the United States and Canada trade liberalization had begun before the signing of NAFTA. The United States entered the GATT in 1947, which resulted in a drop in tariffs on imported goods from 32 percent to 12 percent in 1950, and to 5 percent in 1980. Canada entered the GATT in 1947 and its average tariff in 1989 was 7 percent.

It can then be deduced that when NAFTA was signed, the reduction in tariffs had already been drastic in the United States and Canada (Figure 11). In other words, after the subscription of NAFTA, the reduction in tariffs at the aggregate level was a continuation of what had been done for several decades, which indicates that even without NAFTA the United States and Canada were going to experience low rates of economic growth. Bluestone (2008) has reported that in the 1970s and 1980s there was a loss of 32 million jobs in the United States, while Rosen (2008) has indicated that: "between 1995 and 2004, almost 700,000 firms closed each year, affecting 6.1 million workers, and an additional 1.7 million firms contracted annually, affecting another 11.8 million workers" (Note 2).

It should be noted that the increases in manufacturing export capacity in several countries that occurred in the last decades capitalized on the opening of the economies of developed countries, and increased their exports to them, thus exacerbating their deindustrialization.

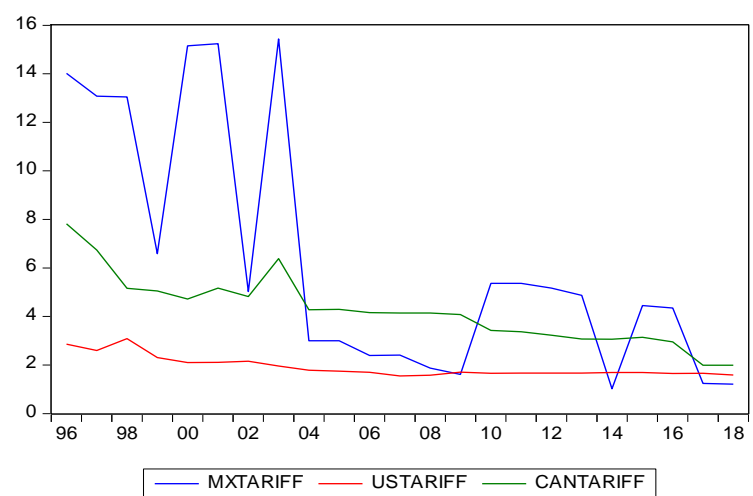

Figure 11. Average tariffs on imports

In Mexico the reduction in tariffs had not been as marked as in the other two countries prior to 1995, but after that year the reduction in tariff rates was drastic. In hindsight, it appears that the three countries had tacitly agreed to opt for deindustrialization and economic stagnation before NAFTA, and they reaffirmed it after the launching of it.

\section{Repercussions on Industrial Employment}

The reduction in tariffs led to the loss of female and male jobs in the industrial sectors, as shown in Figures 12 and 13. It is observed that the fall in female industrial employment is more marked than that of male industrial employment in the three countries, especially in the US and Canada. In Mexico, female industrial employment has had an upward trend after 2014. Male industrial job losses are severe in the US and Canada, while in Mexico this type of employment has increased.

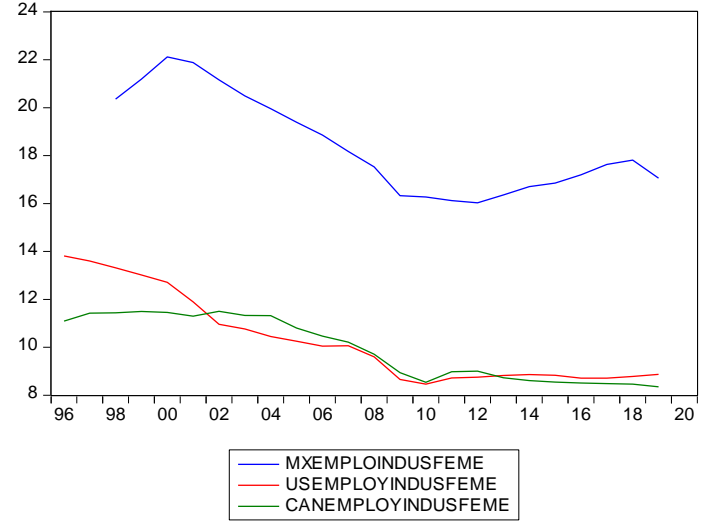

Figure 12. Female industrial employment in Mexico, the United States and Canada

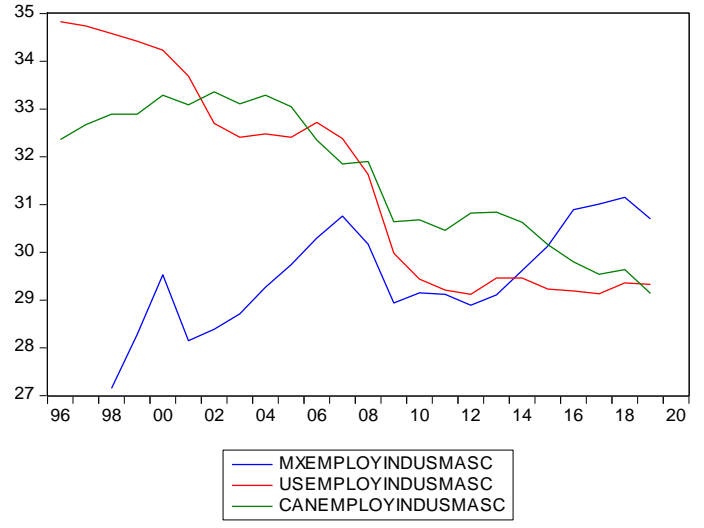

Figure 13. Industrial employment for men in Mexico, the United States and Canada 
Figures 14, 15 and 16 show that the losses of female jobs in the industrial sector have occurred in parallel with the reductions in tariffs. Similar relationships are observed in the cases of male industrial employment.

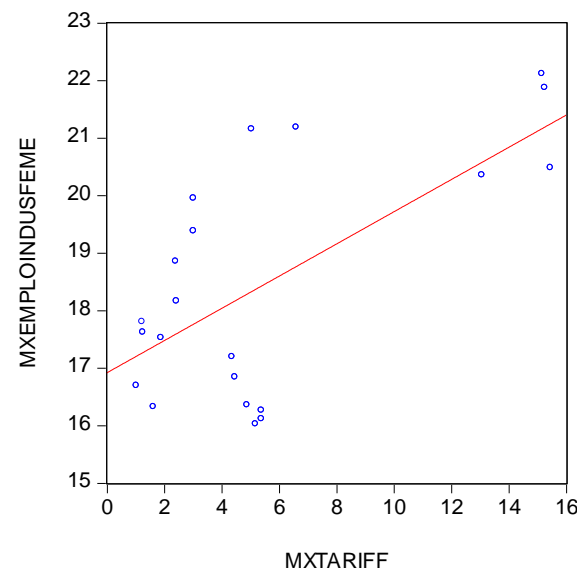

Figure 14. Mexico: Tariff on imports and female industrial employment

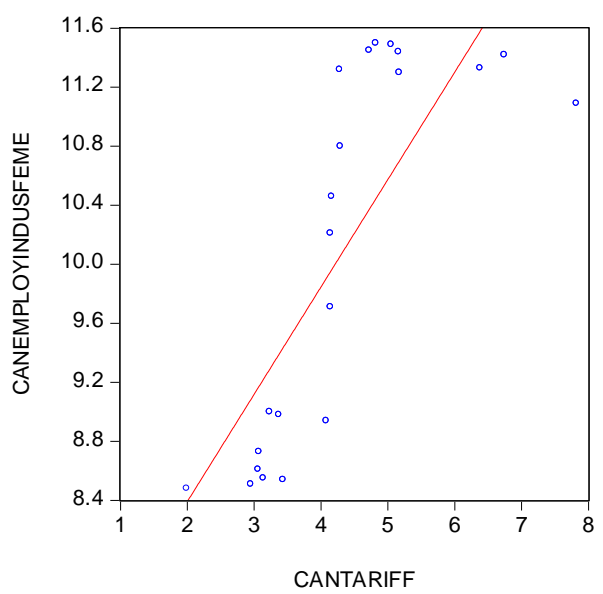

Figure 16. Canada: Tariff on imports and female industrial employment

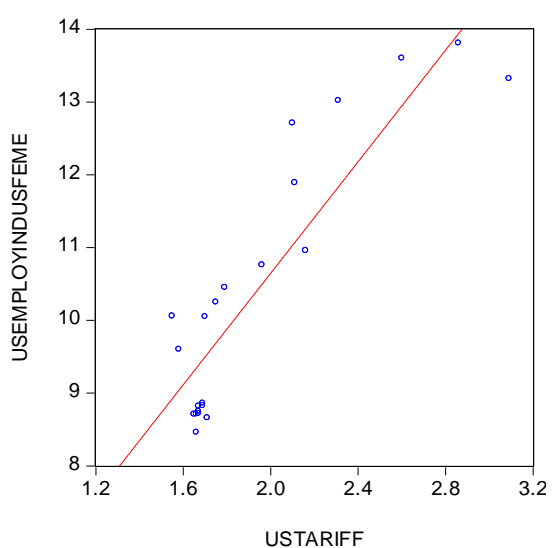

Figure 15. United States: Tariff on imports and female industrial employment

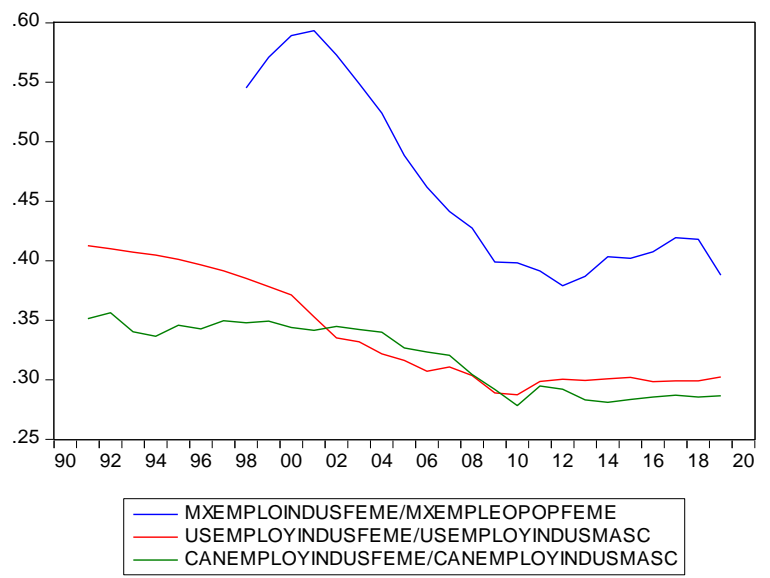

Figure 17. Ratio of female to male industrial employment in Mexico, the United States and Canada.

It should be noted that the ratio of female to male industrial employment has fallen in all three countries, especially in Mexico, as shown in Figure 17, which indicates that there has been a de-feminization of employment in the manufacturing sector.

\section{Economic Growth and the Manufacturing Sector}

Figure 18 consolidates the various processes that result from the liberalization of imports and the consequent economic stagnation. Quadrant (1) shows the positive relationship between openness, (Apertura), that is, the reduction of tariffs, and imports. The reduction in the value added of the manufacturing sector, Manu 1, due to the increase in imports is shown in quadrant (2), relationships that were presented in Figures 5, 6, and 7. Quadrant (3) shows the positive relationship between the percentage of value added of the manufacturing sector in GDP and the rate of economic growth, an association that dates back to the work of Kaldor (1966).

Table 2 shows equations estimated with data from the 1996-2019 period, which express the economic growth rates of Mexico, the United States and Canada in terms of the respective percentages of added values of the manufacturing sector in GDP and of qualitative variables, (Cuali), that take the value of unit in the years that the respective economies experienced economic contractions. It is observed that in the three countries the coefficients of the manufacturing sectors are positive and significant. These results corroborate results obtained by several authors. 
Table 2. Percentage of the manufacturing sector in GDP and economic growth rate.

\begin{tabular}{llll}
\hline & México & EE UU & Canada \\
\hline Constant & -7.2240 & -3.1705 & 0.1411 \\
& $(2.53)$ & $(1.90)$ & $(0.10)$ \\
MXManu & 0.6088 & & \\
& $(3.70)$ & & \\
MXcuali & -4.212 & & \\
& $(5.53)$ & 0.4757 & \\
USManu & & $(3.67)$ & \\
& & -3.9491 & 0.2106 \\
USCuali & & $(6.62)$ & $(1.91)$ \\
& & & -5.9956 \\
CanManu & & & $(4.24)$ \\
& & & 0.51 \\
\hline
\end{tabular}

This represents evidence that the falls in the manufacturing sectors as a consequence of the reduction in tariffs has led to falls in the rates of economic growth. In fact, based on quadrants (1) and (3), quadrant (4) shows the negative relationship between openness and economic growth.

The period of slow growth in the United States since the 1990s has been called the "great moderation" which, according to Cardarelli and Kose (2004), has led to slow growth in Canada; it would be more accurate to call it the "great openness." Given that recessive trends have occurred in the three countries as a consequence of the liberalization of foreign trade, the qualifier that should be applied to the three countries is that they suffer from a "great openness" that has generated a "stagnation triangle".

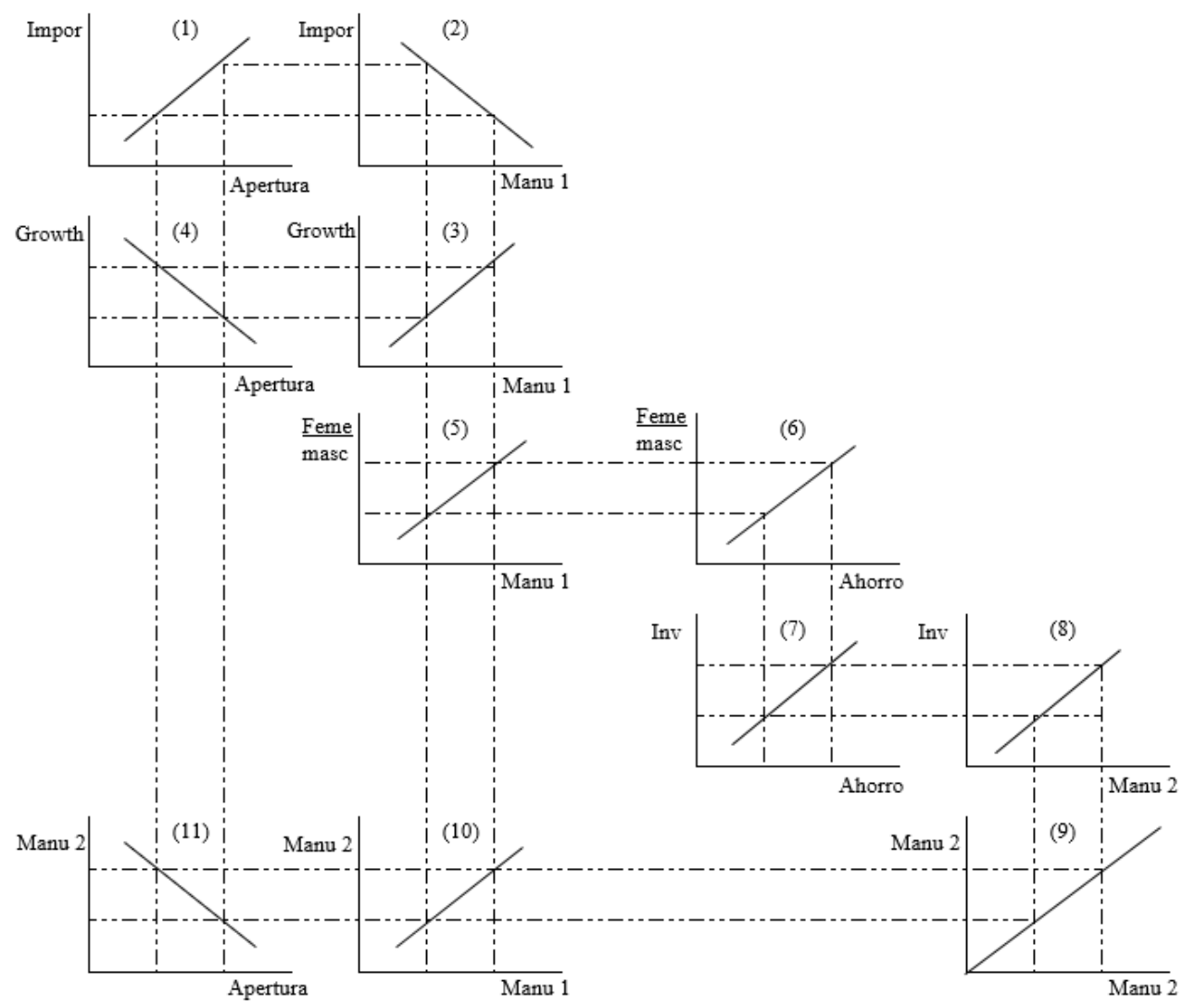

Figure 18. De-feminization of industrial employment 
Figure 16 showed that in the three countries the female to male employment ratios in the industrial sector have fallen in the period under study. This is the relationship shown in quadrant (5) of Figure 18. This relationship is confirmed by the equations presented in Table 3, which express this ratio in terms of the percentages of the manufacturing sector in GDP (Manu). It is observed that the Manu coefficients are positive and significant in the three countries.

Table 3. Ratio of female to male employment in the industrial sector and share of the added value of the manufacturing sector in GDP

\begin{tabular}{llll}
\hline & Mexico & USA & Canada \\
\hline Constant & 0.0863 & 0.0668 & 0.1961 \\
& $(1.95)$ & $(2.61)$ & $(23.71)$ \\
MXManu & 0.0087 & & \\
& $(3.56)$ & & \\
MXCuali & 0.0033 & & \\
& $(0.33)$ & 0.0198 & \\
USManu & & $(9.97)$ & \\
& & -0.0155 & \\
USCuali & & $(1.70)$ & 0.0091 \\
& & & $(14.61)$ \\
CANManu & & & 0.0023 \\
& & & $0.28)$ \\
CANCuali & & 0.92 & 0.93 \\
\hline
\end{tabular}

The implication is that as a result of the economic openness there has been a de-feminization of industrial employment in Mexico, the United States and Canada. In other words, women have lost more in terms of industrial employment than men as a result of trade liberalization. It is also observed that the Manu coefficient corresponding to the United States is around twice that of the other two countries, implying that in the United States deindustrialization has had more weight in the de-feminization of employment in the manufacturing sector.

\section{Implications on Domestic Savings}

Seguino and Floro (2003) have presented evidence showing that the increase in the female to male employment ratio in a country leads to increases in its domestic savings rate, which they explain by drawing evidence from several studies that employment grants women greater capacity to decide on the destination of the household budget and therefore allows them to allocate greater amounts of resources to caring for children and to saving. The authors presented evidence from a sample of 70 countries that corroborated this point. Caceres (2020) also presented similar evidence with a cross-data sample from 17 Latin American countries, as well as for the cases of Guatemala (Caceres, 2021b) and Honduras (Caceres, 2021c). This implies that the fall in the female to male employment ratio shown in Figure 17 has implications for the mobilization of domestic savings. This relationship is shown in quadrant (6).

Table 4 presents equations that corroborate this relationship, since the coefficients of said Ratio are positive and significant; it should be noted that in the case of Mexico the Ratio variable represents the ratio of female to male employment in the service sector, since when employment data from the industrial sector were used, no significant relationship was obtained. 
Table 4. Female to male employment ratio and domestic savings rate.

\begin{tabular}{llll}
\hline & Mexico & United States & Canada \\
\hline Constante & -30.9628 & 5.0941 & 9.9299 \\
& $(3.06)$ & $(2.76)$ & $(2.87)$ \\
MX Ratio employm* & 34.5208 & & \\
& $(5.23)$ & & \\
MX CualiS** & 3.8991 & & \\
US Ratio employm & $(8.25)$ & 40.6686 & \\
& & $(8.24)$ & \\
US Cuali & & -1.9498 & \\
& & $(2.78)$ & 43.5123 \\
CAN Ratio employm & & & $(3.80)$ \\
& & & -2.2446 \\
CANCuali & & 0.80 & $(2.00)$ \\
R squared & 0.64 & & 0.45 \\
\hline
\end{tabular}

* Ratio employm represents the employment ratio in the service sector.

** MxCualiS represents the period 1996-1999 when the domestic savings rate had high values.

These equations indicate that the de-feminization of employment leads to a fall in household savings. Figure 19 shows that domestic saving rates have fallen in the three countries, but to a lesser degree in Mexico, a country where the de-feminization of industrial employment has not been as marked as in the other countries.

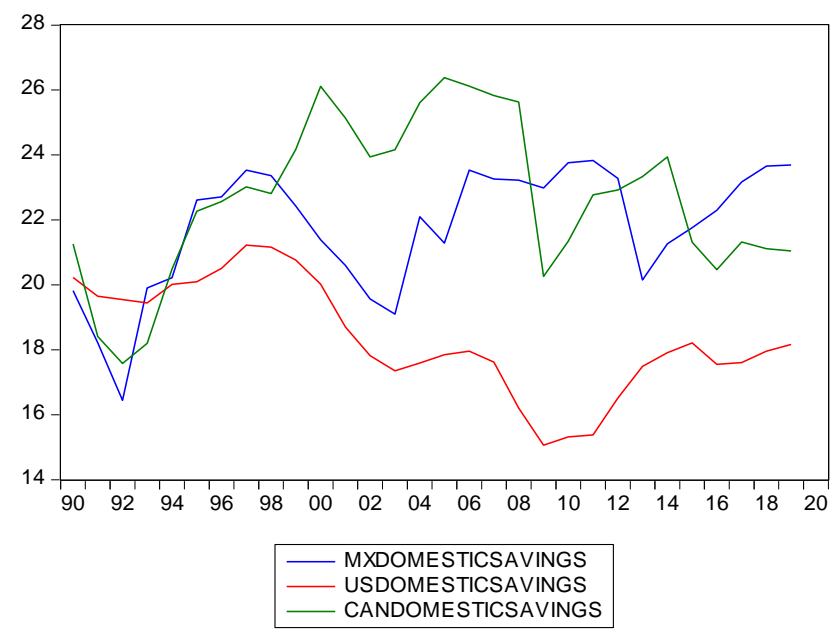

Figure 19. Domestic savings rates

The reduction in domestic saving leads to a fall in investment, as stated in quadrant (7). Table 5 presents the investment rates in terms of domestic and foreign savings rates. It is observed that in the three countries their savings rates have positive and significant coefficients. The external saving rate, that is, the negative of the current account deficit, has significant coefficients in the United States and Canada, negative in the first and positive in the second, results that contradict the paradox of Feldstein and Horioka (1980) that maintains that domestic investment rests exclusively on domestic savings (Note 3). In the United States and Canada, investment is partially based on international capital mobility; it should be noted that Klyuev (2008) has presented data showing that about half of the placement of Canadian corporate bonds takes place in the financial markets of the United States. The external savings rate was not significant in the case of Mexico, and thus the Feldstein-Horioka paradox prevails. 
Table 5. Investment rates and domestic and external savings

\begin{tabular}{llll}
\hline & Mexico & United States & Canada \\
\hline Constant & 7.4112 & 4.9824 & \\
MXDomesticSavings & $(2.48)$ & $(5.45)$ & \\
& 0.6208 & & \\
MXCuali & $(2.48)$ & & \\
& -1.0428 & & \\
USDomesticSavings & $(2.10)$ & 0.7823 & \\
& & $(15.15)$ & \\
USExternalSavings & & -0.6672 & 0.8862 \\
& & $(14.15)$ & $(4.21)$ \\
CANDomesticSavings & & & 1.1684 \\
& & & $(6.35)$ \\
CANExternalSavings & & & -1.0745 \\
CANCuali & & & $(1.30)$ \\
R squared & & 0.77 & 0.97 \\
\hline
\end{tabular}

There is evidence from Latin American countries that investment constitutes additional productive capacity and that its increase results in curbing deindustrialization (Caceres, 2021a). Therefore, it is valid to state in quadrant (8) that the fall in investment as a result of the fall in the employment ratio gives rise to another fall in the share of the value added of the manufacturing sector in GDP, Manu2.

Table 6 shows equations that represent the added value of the manufacturing sector as a percentage of GDP in terms of investment; it is observed that in the USA and Canada the coefficients are positive and significant, but in Mexico the coefficient is negative, and the R squared is very low.

Table 6. Percentage of the manufacturing sector and investment rate

\begin{tabular}{llll}
\hline & México & United States & Canada \\
\hline Constant & 36.1005 & -3.9994 & -7.4035 \\
& $(4.94)$ & $(0.73)$ & $(0.64)$ \\
Mx Investment & -0.8961 & & \\
& $(2.61)$ & & \\
US Investment & & 0.8000 & \\
CAN Investment & & $(3.08)$ & 0.8620 \\
& & & $(1.93)$ \\
R squared & 0.18 & 0.43 & 0.21 \\
\hline
\end{tabular}

Using the 45-degree line shown in quadrant (9), a positive relationship between Manu1 and Manu2 is obtained in quadrant (10), which indicates that the initial deindustrialization generates a subsequent deindustrialization, thus giving persistence to this process. Quadrant (12) indicate that the original openness determines subsequent deindustrialization.

This implies that trade liberalization creates a series of vicious cycles that impart persistent stagnation tendencies to economies. That this process does not lead to a severe production and employment crisis is explained by the investments, mainly in technology and education, that the countries undertake, which results in increases in labor productivity. Cardarelli and Klose (2004) have pointed out that the labor productivity of the US economy grows persistently thanks to the high investment in computer science technologies that reaches 6 percent of GDP, higher than the corresponding value of 4 percent in Canada.

In Figure 18 it can be shown if the country in question undertakes high investments that impart greater productivity to the manufacturing sector, the relationship between investment and manufacturing shown in quadrant (8) would shift downwards, which implies that manufacturing would be better positioned to compete with imports, and thus reindustrialization would become feasible. This highlights the importance of public 
investment to pave the path to private investment in new and high productivity sectors.

Another variable that helps prevent crises derived from deindustrialization is investment in research and development. In this area, Mexico shows extremely low values, as can be seen in Table 7.

Table 7. Annual investment in Research and Development (Percentage of GDP).

\begin{tabular}{cccc}
\hline Year & Mexico & United States & Canada \\
\hline 2000 & 0.31 & 2.63 & 1.86 \\
2005 & 0.40 & 2.52 & 1.98 \\
2010 & 0.49 & 2.73 & 1.83 \\
2015 & 0.44 & 2.72 & 1.70 \\
2018 & 0.31 & 2.72 & 1.70 \\
\hline
\end{tabular}

The declining trends of this investment in Mexico and Canada are striking; after the launching of NAFTA these two countries were entering the "big leagues", which would have motivated them to increase investments in scientific and technological areas.

\section{Deindustrialization, Employment Ratio and External Solvency}

The falls in female to male employment ratios as a result of deindustrialization have implications in relation to the external solvency of a country. This is analyzed on the basis of identity:

Trade account deficit $=\mathrm{M}-\mathrm{X}=\mathrm{I}-\mathrm{S}$

Where $\mathrm{M}=$ imports, $\mathrm{X}=$ exports, $\mathrm{I}=$ investment and $\mathrm{S}=$ domestic savings, with all variables expressed as percentages of GDP.

Given that $\mathrm{S}$ is determined by the female to male employment ratio, (Table 4), the previous expression can be written like this:

Trade account deficit $=\mathrm{I}-\mathrm{a}$ (Ratio female to male employment),

where a is a coefficient. Equations that express the deficit in the trade account in terms of investment and the employment ratio are presented in table 8 . It is observed that in the three countries the investment rate has positive and significant coefficients, and those of the ratios of female to male employment are negative and significant. These results show that the increase in the female relative to male employment ratio contributes to reducing the deficits in the trade account.

Table 8. Determinants of the trade account (M-X).

\begin{tabular}{llll}
\hline & Mexico & USA & Canada \\
\hline Constant & 12.8983 & -2.3347 & 132.7498 \\
MXRatio employm* & -16.9125 & & \\
& $(3.06)$ & & \\
MXInvestment & 0.6776 & & \\
& $(5.12)$ & & \\
USRatio employm** & & -26.0064 & \\
US Investment & & $(5.77)$ & \\
& & 0.6692 & -111.4143 \\
CAN Ratio employm* & & $(4.53)$ & $(5.75)$ \\
CAN Investment & & & 0.7552 \\
R squared & & & $(4.23)$ \\
\hline
\end{tabular}

* Refers to the ratio of employment in services.

** Refers to the employment ratio in the industrial sector.

It should be noted that several authors (Santos, 2002; Santos\& Thirlwall, 2004) have shown that the most emblematic result of the liberalization of foreign trade in developing countries has been high deficits in the trade account; this may be a reflection of the fall in the female to male employment ratio, that is, the de-feminization 
of employment generates deterioration in the commercial account.

The implication is that female employment is an instrument of financial prudence insofar as it contributes to keeping external accounts at adequate values. Another implication is that closing gender gaps in employment is a stabilization measure for the external sector that can be as effective as devaluation (without provoking a recession). Likewise, it is valid to state that a country that resorts to devaluation in the face of deterioration in its commercial account may obtain null results from this measure if its economy is experiencing a process of de-feminization of employment. The fall in the female to male employment ratio leads to an increase in the demand for external savings to sustain investment which, given the persistence of deindustrialization, may lead the economy to experience severe problems of external indebtedness. In other words, gender inequality can occur in parallel with instability in external accounts and recurring external debt crises.

\section{Ratio of Female to Male Employment and Economic Growth}

It is shown below that the female to male employment ratio determines the economic growth rate in the framework of Thirlwall (1979), a model where growth is restricted by the balance of payments.

The starting point is the equilibrium condition of the trade account:

$\mathrm{M}-\mathrm{X}=\mathrm{I}-\mathrm{a}($ Ratio (employment $)=0$.

And therefore: $\mathrm{I}=\mathrm{a}$ (Employment ratio).

Based on Harrod-Domar, the economic growth rate is equal to:

$\mathrm{y}=\mathrm{I} / \mathrm{k}=(\mathrm{a} / \mathrm{k})$ Employment ratio), where $\mathrm{k}$ is the capital output ratio.

The previous expression was estimated for the three countries but the results were satisfactory only in the cases of the United States and Canada.

The equations are shown in Table 9 for the cases of employment ratios in the industrial and service sectors.

Table 9. Ratios of female to male employment and economic growth rates

\begin{tabular}{|c|c|c|c|c|}
\hline \multirow[b]{2}{*}{ Constant } & \multicolumn{2}{|c|}{ USA } & \multicolumn{2}{|c|}{ Canada } \\
\hline & -3.9055 & -4.2858 & -6.3636 & -6.3763 \\
\hline Cuali & $\begin{array}{c}-3.9055 \\
(2.35)\end{array}$ & $\begin{array}{c}-4.2558 \\
(5.58)\end{array}$ & $\begin{array}{c}-6.3636 \\
(1.27)\end{array}$ & $\begin{array}{c}-6.3763 \\
(6.37)\end{array}$ \\
\hline US Ratio industrial & $\begin{array}{c}20.8264 \\
(4.11)\end{array}$ & & & \\
\hline US Ratio services & & $\begin{array}{c}25.7958 \\
(2.61)\end{array}$ & & \\
\hline CAN Ratio industrial & & & $\begin{array}{c}20.1663 \\
(2.22)\end{array}$ & \\
\hline CAN Ratio services & & & & $\begin{array}{c}43.8995 \\
(2.31)\end{array}$ \\
\hline R squared & 0.73 & 0.65 & 0.64 & 0.65 \\
\hline
\end{tabular}

\section{Extension to Several Countries}

The growth rate of a country's 1 imports, $\mathrm{m} 1$, is given by: $\mathrm{m} 1=\mathrm{b} 1 \mathrm{y} 1$, where $\mathrm{b} 1$ is the income elasticity of imports and $\mathrm{y} 1$ is the economic growth rate.

Therefore, the growth of imports can be written in terms of the ratio of female to male employment: $\mathrm{m} 1=\mathrm{b} 1 \mathrm{y} 1$ $=\mathrm{b} 1(\mathrm{a} 1 / \mathrm{k} 1)$ (Employment ratio)

According to the Thirlwall model, the condition for the trade account to remain in balance is the following: b1y1 $=\mathrm{m} 1=\mathrm{x} 1$, where $\mathrm{x} 1$ is the growth rate of exports.

It must be taken into account that $\mathrm{x} 1$ depends on the economic growth of the countries to which country 1 exports, that is:

$\mathrm{m} 1=\mathrm{b} 1(\mathrm{a} 1 / \mathrm{k} 1)($ Employment ratio1) $)=\mathrm{x} 1=\mathrm{b} 21(\mathrm{a} 2 / \mathrm{k} 2)($ Employment ratio2) $+\mathrm{b} 31(\mathrm{a} 3 / \mathrm{k} 3)($ Employment ratio3) $+\ldots$ where $b 21$ and $b 31$ are the income elasticities of countries 2 and 3 that country 1 imports from.

Solving for the growth rate of country 1 , it is obtained that:

$\mathrm{y} 1=(\mathrm{b} 21 / \mathrm{b} 1)(\mathrm{a} 2 / \mathrm{a} 1)(\mathrm{k} 1 / \mathrm{k} 2)($ Employment Ratio2) $+(\mathrm{b} 31 / \mathrm{b} 1)(\mathrm{a} 3 / \mathrm{a} 1)(\mathrm{k} 1 / \mathrm{k} 3)$ Employment Ratio3 +... 
This expression can be written as: $\mathrm{y} 1=\mathrm{V} 2$ Ratio employment $2+\mathrm{V} 3$ Ratio employment $3+\ldots \ldots \ldots$

Where Vi is equal to (bi1 / b1 (ai / a1) (k1 / ki) (Employment ratioi)

This expression indicates that the growth rate of country 1 depends on its structural characteristics and those of the other countries; it depends on its income elasticity of its imports b1 and those of the other countries, bi1; its propensity to invest, a1, and those of other countries ai; on their capital-product ratio and those of the other countries. And, of course, it depends on its employment ratio and those of the other countries. This expression indicates that closing the gender gap in one country has positive repercussions on the economic growth of the other countries.

One implication is that the commitment of NAFTA member countries to promote the closing of gender gaps can lead to reversing economic stagnation trends. Therefore, it is valid to infer that closing gender gaps in employment constitutes a regional externality, insofar as it boosts the countries' economic growth.

It should be noted that in a recent study, Arora and Vamvakidis (2004) highlighted the importance for the economic growth of a country that it has commercial relations with countries that experience dynamism in their economic growth. From this result it can be argued that the benefit for the given country resides in its trade relations with countries whose gender gaps are low, or that are making progress in closing them. The implication is that increasing world trade demands global actions to reduce gender gaps in employment. Closing gender gaps can be a more appropriate policy to increase trade than tariff reduction.

\section{Cointegration of Economic Growth Rates and Employment Ratios}

In the framework of the economic growth model restricted by the balance of payments, Caceres (2021d) has shown that within the framework of Central American economic integration, the growth rates of the member countries are cointegrated, denoting that their economic dynamism is restricted by the balance of payments. One extension is that the existence of cointegration can be analyzed using the female-to-male employment ratios of the countries to represent their economic growth rates.

The expression to be analyzed is: Employment ratio11 = Z2 Employment ratio21) + Z3 (Employment ratio31)... $+\mathrm{Zi}$ (Employment ratioij) Where ij represents country $\mathrm{i}$ and sector $\mathrm{j}$. This expression indicates that under the Thirlwall model of growth restricted by the balance of payments, the employment ratios of the countries are interdependent. To investigate the existence of interdependence, cointegration tests were carried out to determine whether the trajectory of employment ratios in the industrial sector were subject to reciprocal relationships of interdependence. The application of Johansen's methodology yielded the following results of the trace statistic:

Table 10. Cointegration test, employment ratios in the industrial sector.

\begin{tabular}{lllll}
\hline Hypothesized & & Trace & 0.05 & Prob.** \\
No. of CE(s) & Eigenvalue & Statistic & Critical Value & 0.0000 \\
None $*$ & 0.794901 & 52.15335 & 29.79707 & 0.0082 \\
At most $1 *$ & 0.520103 & 20.46807 & 15.49471 & 0.0162 \\
At most $2 *$ & 0.251153 & 5.784418 & 3.841466 & \\
\hline
\end{tabular}

These results indicate that the female to male employment ratios in the industrial sector of the three countries give rise to three cointegration vectors. The first vector is the following:

RatioEmployMexico = 1.7907 RatioEmployUS + 0.4970 RatioEmployCanada

$$
\text { (0.36) (0.44) }
$$

It is observed that the coefficient corresponding to Canada is not significant.

This exercise was repeated using the employment ratios in the service sector, with the following results:

Table 11. Cointegration test of female to male employment ratios in the service sector.

\begin{tabular}{lcccc}
\hline Hypothesized & & Trace & 0.05 & \\
\hline No. of CE(s) & Eigenvalue & Statistic & Critical Value & Prob.*** \\
None & 0.358318 & 18.60867 & 29.79707 & 0.5213 \\
At most 1 & 0.183162 & 7.960778 & 15.49471 & 0.4696 \\
At most 2 & 0.121364 & 3.10523 & 3.841466 & 0.0780 \\
\hline
\end{tabular}


It is observed that there is no cointegration between the employment ratios in the service sector, which could be explained by the fact that this sector does not produce tradable goods, contrary to the situation in the industrial sector; this shows that the relations of cointegration results from commercial transactions between countries.

From this result it can be inferred that developing countries whose trading partners have high shares of the services sector in GDP may experience stagnation tendencies, since they would not benefit from high spillovers of economic growth generated by trading partners.

\section{Principal Components of Employment Ratios}

An extensive literature has investigated the impact of export growth, $x 1$, on economic growth, $y 1$, of a given country, country 1 for example, estimating equations of this type: $y 1=h+v x$, where $h$ and $v$ are coefficients.

In this expression $\mathrm{x}$ is the sum of the growth rates of exports to different countries that import from country 1 , weighted by the share of such exports in total exports.

Therefore, the economic growth rate of the country can be written like this:

$\mathrm{y} 1=\mathrm{Wvi}($ Employment ratioi), where $\mathrm{W}$ represents the summation sign.

Given that employment ratios differ between countries for institutional and other reasons, and that the weights of the different sectors in GDP are different, not taking these differences into account can lead to biased values of the coefficients of the estimated equations.

To investigate the existence of common trends in the series of Nafta members' industrial employment ratios, the principal components of these variables were estimated, and are shown in table 12.

Table 12. Principal components of industrial employment ratios.

\begin{tabular}{lccccc}
\hline Eigenvalues: $($ Sum = 3, Average = 1) & \multicolumn{5}{l}{} \\
\hline Number & Value & Difference & Proportion & Cumulative Value & Cumulative Proportion \\
\hline 1 & 2.807545 & 2.659080 & 0.9358 & 2.807545 & 0.9358 \\
2 & 0.148465 & 0.104474 & 0.0495 & 2.956009 & 0.9853 \\
3 & 0.043991 & --- & 0.0147 & 3.000000 & 1.0000 \\
\hline Eigenvectors (loadings): & PC 1 & PC 2 & PC 3 & \\
Variable & & & & \\
MXEMPLOINDUSFEME/MXEMPLOYI & 0.587678 & -0.122772 & -0.799726 & \\
NDUSMASC & & & & \\
USEMPLOYINDUSFEME/USEMPLOYI & 0.569024 & 0.765392 & 0.300645 & \\
NDUSMASC & & & & \\
CANEMPLOYINDUSFEME/CANEMPLO & & & & \\
YINDUSMASC & 0.575193 & -0.631746 & 0.519664 & \\
\hline
\end{tabular}

It is observed in the table 12 that there are three principal components and that the first one explains almost all the variance of the variables. That is, the common variation is so great that only one principal component is enough to represent the variables.

The principal components are:

$\mathrm{PC} 1=0.5877 \mathrm{MX}$ Ratio $+0.5690 \mathrm{USR}$ atio +0.5752 CANRatio

$\mathrm{PC} 2=-0.1228 \mathrm{MXRatio}+0.7654$ USRatio -0.6317 CANRatio

PC3 $=-0.7998$ MXRatio +0.3006 USRatio +0.5196 CANRatio

In the first component, the variables have very similar coefficients, which can indicate that this component represents NAFTA, that is, the integration of the three economies; or it could represent the economic liberalization that has been common to the three economies. The second component can represent the United States, given the high value of the coefficient corresponding to this country $(0.7654)$, while the third can represent Mexico, reflecting the difference between the high loadings of Mexico and those of the other two countries.

The point to be emphasized is the existence of a principal component that explains almost all the variance in the ratios of female to male industrial employment in the three countries, which denotes the existence in North America of an integrated economic region. 


\section{Importance of demoFigureic Variables}

To investigate the role of demographic variables in Mexico's economic growth, the female to male employment ratios are presented below in Figure 20.

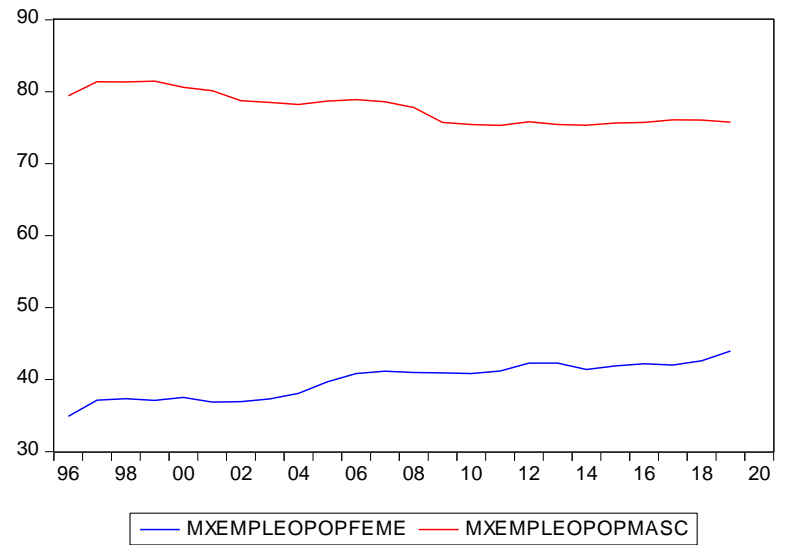

Figure 20. Ratios of female and male employment to population

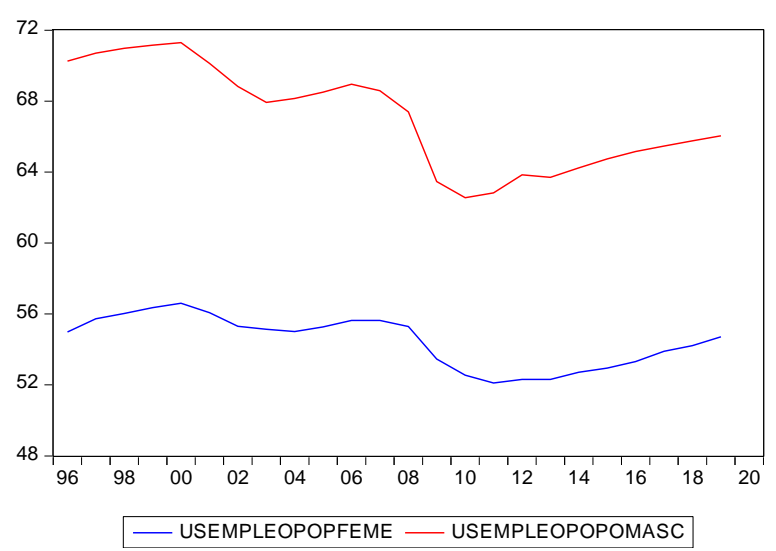

Figure 21. Ratios of female and male employment to US population

It is observed that in Mexico female employment shows an upward trend throughout the period, which contrasts with the declining trend of male employment. Female employment tends to increase in times of economic crisis, such as in 2002 and 2009, which is not observed in male employment. These increases are not observed in the other two countries.

In the United States, (figure 21), female and male employment show declining trends until 2009, and as of that year they begin to increase, but their 2019 values did not exceed those of 2007, prior to the global crisis. It should be noted that male employment has more severe falls than female employment.

Figure 22 shows that the trajectory of female employment in Canada does not have abrupt changes and, contrary to the other two countries, shows an upward trend until 2009 when it falls and remains constant until 2016, and thereafter it grows slightly in the rest of the period. It should be noted that in Canada female employment shows higher values than those of the other two countries and did not experience the deep contractions shown by the US and Mexico. Male employment shows a similar trajectory with weak anticyclical variations in relation to female employment.

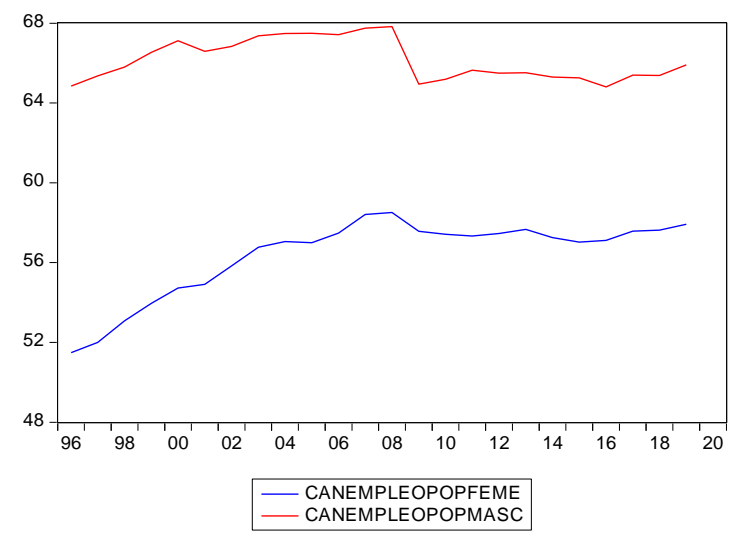

Figure 22. Ratios of female and male employment to population in Canada

Figure 23 shows the trajectories of the ratios of female to male employment in the three countries. The ratio in Mexico shows an upward trend but its values are below those of the two countries. It is observed that in Canada there has been a clear trend towards greater feminization of the economy, which is also noticeable to a lesser degree in the US.

It should be emphasized that the feminization of the economy in Canada has grown more appreciably than in the others two countries. The increases in these ratios in the year of economic crisis, 2009, are more pronounced in 
the United States and Canada, indicating that women increased their labor force participation to safeguard household finances. In Mexico, the increase of this ratio was not marked in the crisis years 2002 and 2009, indicating that women entered the labor market to compensate for the loss of employment of men, but to a lesser degree than in other countries. Therefore, it should be noted that in the NAFTA countries female workers constitute a true instrument of economic stabilization.

The low female to male employment ratio of Mexico means the existence of an important potential for economic development that can be activated by closing the gender employment gaps. The low volatility of the female-to-male employment ratio in Canada can be associated with the evidence presented by Tsounta (2006) that the public policy adopted by this country to expand childcare services at prices that permit access to women from low income levels, led to the significant entry of women into the labor market, and has imparted stability to household finances. This explains the high feminization of employment that is observed in Figure 23. High feminization of employment implies high savings rates and solid external solvency.

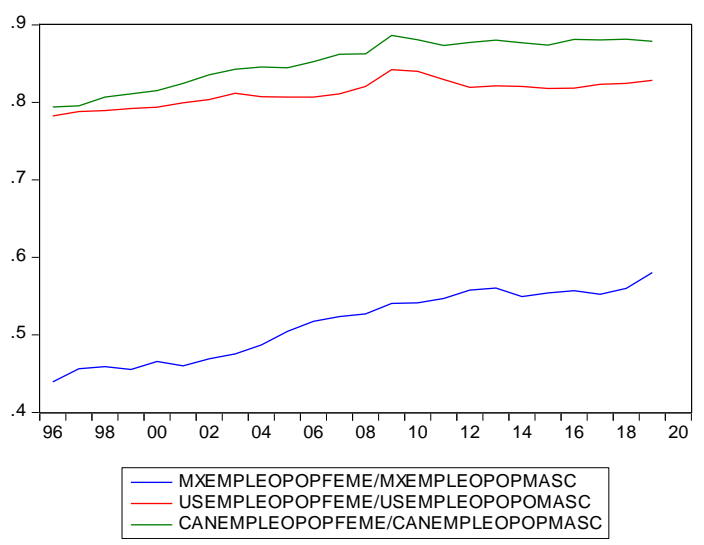

Figure 23. Female to male employment ratios

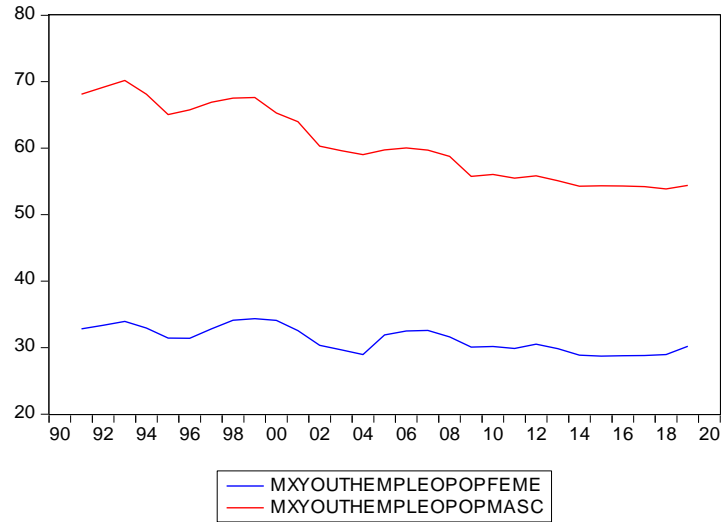

Figure 24. Ratios of youth employment to population, female and male in Mexico

In Mexico, both female and male youth employment show a tendency to fall (Figure 24), but it is more accentuated in the case of male youth employment, which is related to the high propensities of young people to emigrate.

The trajectories of female and male youth employment in the US are bumpy and the decline in 2009 is deep; a persistent recovery is observed in 2010, but at the end of the period both ratios were below the values corresponding to the beginning of the period (Figure 25). It should be noted that the trajectories of female and male youth employment converge in 2008-2010, and also in 2018, which indicates that the crises "feminize" youth employment.

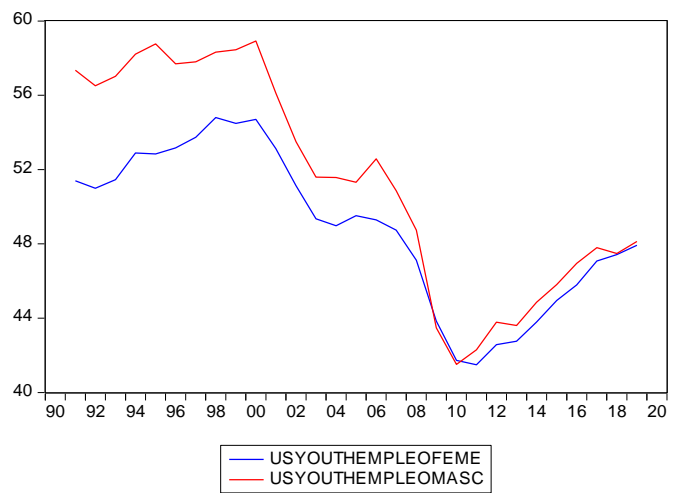

Figure 25. Ratios of youth employment to population, female and male in the United States

It should be emphasized that in Canada, female youth employment surpassed male youth employment in 2002, and in the global crisis of 2008-2009 it fell less sharply than male youth employment. As of 2002, female youth employment shows higher rates than that of males. This can be associated with the enactment of the childcare access policy. It should be noted that only in Canada female youth employment in 2019 was higher than the 1991 value. 


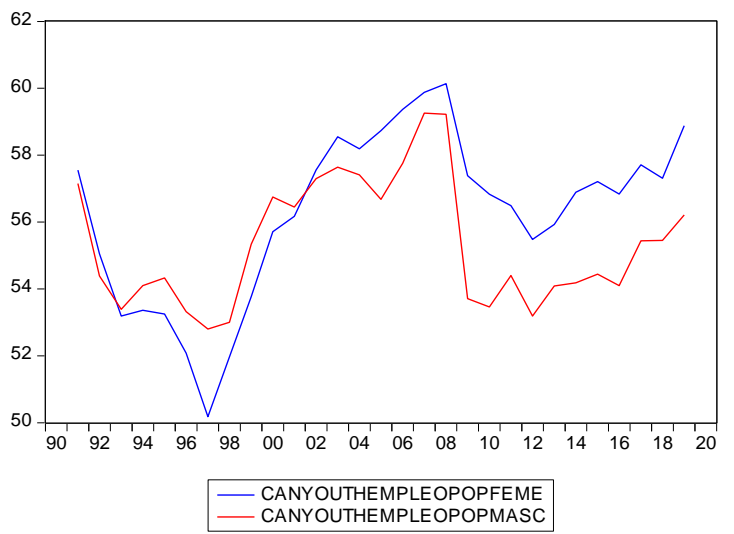

Figure 26. Ratios of youth employment to population, female and male in Canada

It is observed in Figures 24, 25, and 26 that the trajectories of these ratios are more uneven than those corresponding to the total population, which highlights the fact indicated by Dunsch (2016) and Scarpetta, Sonnet and Manfredi (2010), that young people are the first ones to lose their jobs in cases of economic downturns.

\section{Migration and Youth Employment in Mexico}

To appreciate the causes of the falls in female and male youth employment in Mexico, the Figures 27 and 28 show that female and male youth employment have inverse relationships with the remittances received by Mexico as percentages of GDP, that is, to higher amounts of remittances relative to GDP, the lower the ratio of youth employment to population. Remittances represent the emigration of the past, so that their increase would represent the increase in emigration and hence, lower youth employment.
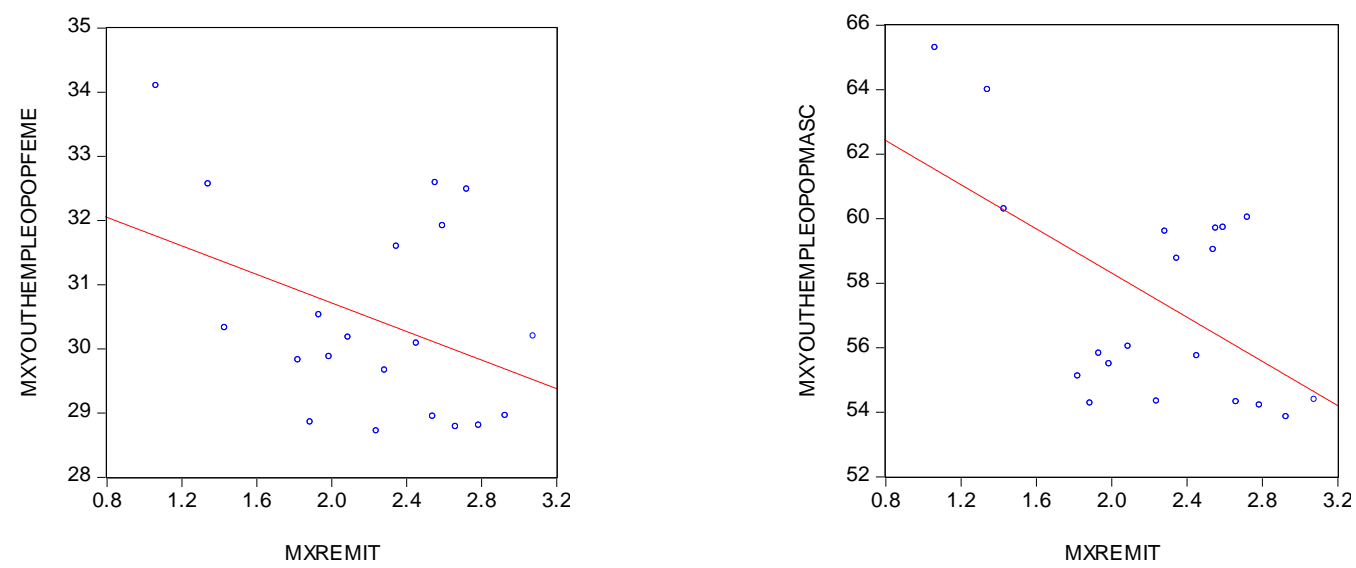

Figure 27. Remittances as a percentage of GDP (MXRemit), Figure 28. Remittances as a percentage of GDP and female youth employment, 1991-2019 and male youth employment, 1991-2019

Given the drop in the youth employment to population ratio in Mexico, a valid inference is that the emigration of its youth, represented by remittances, has a high cost for Mexico since it has a negative impact on economic growth, as observed in the following estimated equation with data from 1996-2019:

MXGrowth $=5.4006-4.7400 \mathrm{MXCuali}-1.0607 \mathrm{MXRemit}$

$$
\text { (4.07) (4.00) (1.70) }
$$

$\mathrm{R}$ squared $=0.51$

Where MXGrowth is the annual growth rate of Mexico, and MXRemit is the inflow of remittances as a percentage of GDP.

It is appropriate to take into account the case of China, Mexico's third trading partner, whose ratios of female and male employment to population show persistent declining trends, especially female (Figure 29). This could reflect the aging of the population; in this regard, a study by Steinberg and Nakane (2012) argued that "Women 
can Save Japan" in view of the increase in female employment that would result from changes in tax policy and the expansion of childcare facilities in that country, approaches that are also valid for the case of China.

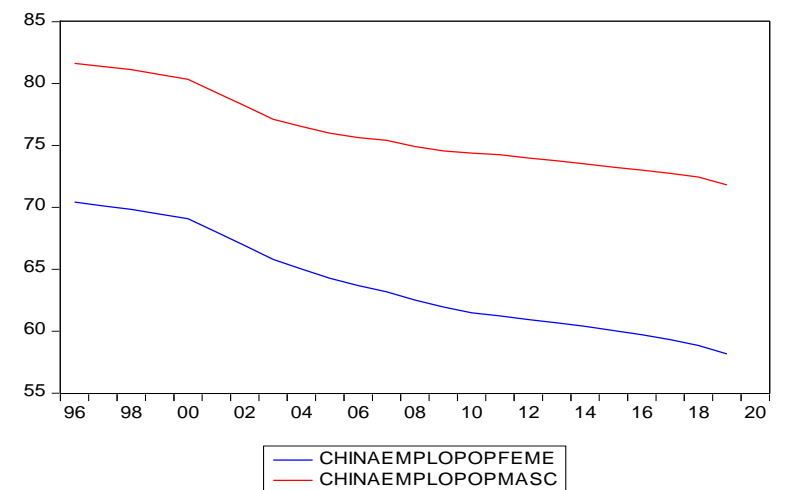

Figure 29. Employment ratios to the female and male population in China

\section{DemoFigurey and Economic Growth}

To investigate the role of female and male employment, as well as of labor productivity in economic growth, the following is used: $\mathrm{Y} / \mathrm{P}=(\mathrm{Y} / \mathrm{L}) \mathrm{x}(\mathrm{L} / \mathrm{P})$

where $\mathrm{Y}$ is the GDP, $\mathrm{P}$ is the total population, $\mathrm{L}$ is the employed population, $(\mathrm{Y} / \mathrm{L})$ is labor productivity, and (L/ $\mathrm{P})$ is the ratio of employment to population.

In terms of logarithms this expression is equal to: $\log (\mathrm{Y} / \mathrm{P})=\log (\mathrm{Y} / \mathrm{L})+\log (\mathrm{L} / \mathrm{P})$.

Taking the derivatives of the previous expression, it is obtained that the growth rate of GDP per capita is determined by the growth rate of labor productivity plus the growth rate of the employment-to-population ratio. This equation was estimated with data from the 1996-2019 period, with the following results:

Growth GDP per capita $=0.0062+0.9899$ GrowthProductivity +

\subsection{GrowthEmploypopfeme + 0.6253GrowthEmploypopmasc}

\section{$\mathrm{R}$ squared $=0.99$}

It is observed that all the coefficients have the expected signs and are significant and the R squared is very high. It should be emphasized that the coefficient of labor productivity is close to unity, which shows the importance of labor productivity in Mexico's economic growth. Labor productivity in Mexico shows stagnation and is very unstable (Figure 30). This can be associated with the de-feminization of industrial employment; reference should be made to the evidence for 60 countries presented by Greenstein and Anderson (2008), indicating that countries where the ratio of female to male industrial employment are low tend to have low competitiveness.

Labor productivity in the United States and Canada show persistent growth, especially in the first country (Figure 31).

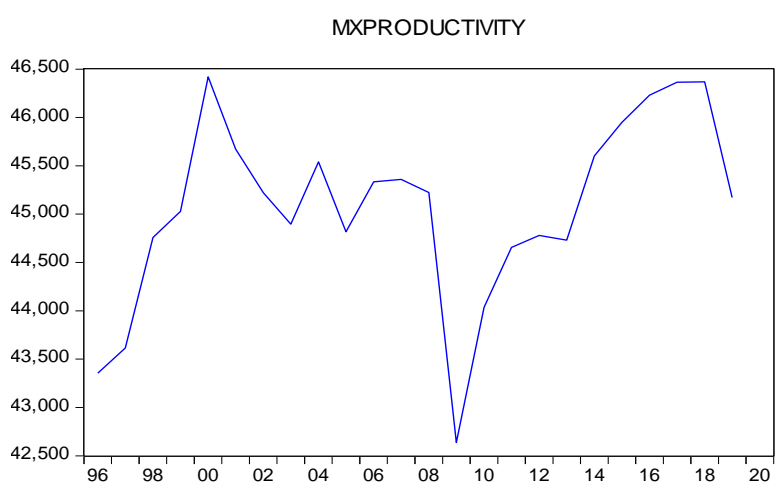

Figure 30. Labor productivity in Mexico

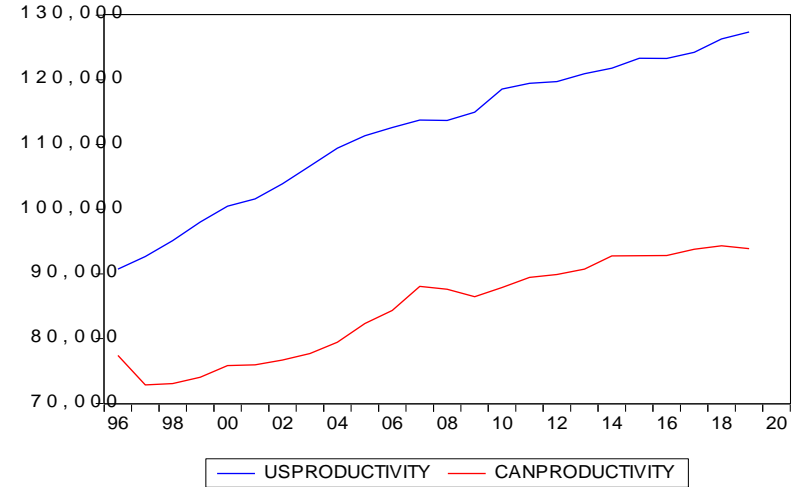

Figure 31. Labor productivity of the United States and Canada 
Faced with stagnant and declining productivity, Mexico's economic growth has been supported by female employment, while the United States and Canada have compensated for the drops in female and male employment with persistent productivity growth.

By multiplying the values of the coefficients of the estimated equation by the annual values of the respective variables, the contributions of these variables to the growth of per capita GDP in Mexico are obtained. Productivity contributions are very unstable, in most years they are positive but of low value (Figure 32).

MXCONTRPRODUCTIVITY

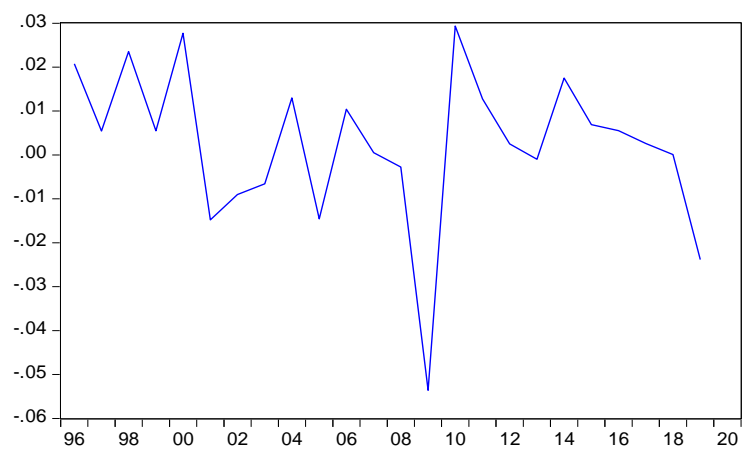

Figure 32. Contributions to the growth of GDP per capita originated in the growth of labor productivity

It should be noted that in most of the period the contributions of the growth of male employment are negative, while those of the growth of female employment are mostly positive. In the entire period 1996-2019, the contribution of male employment was negative on average, while the average value of the contribution of female employment was positive. In other words, the growth of GDP per capita in Mexico has been driven by the feminization of employment.

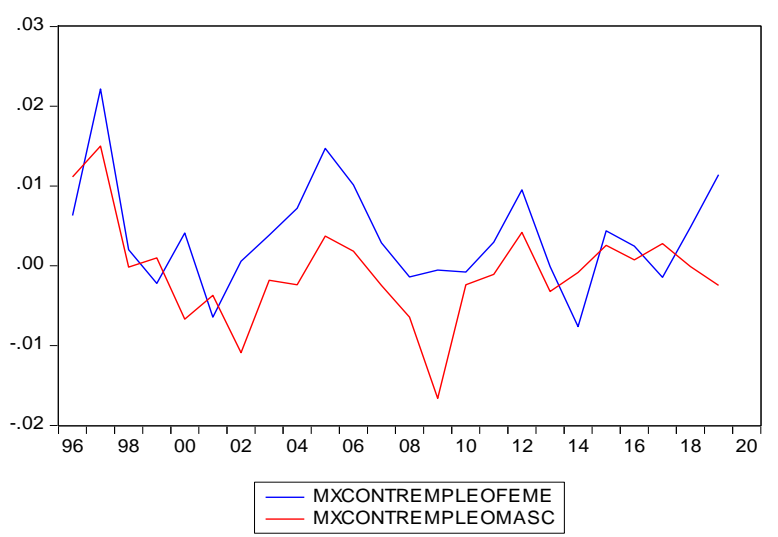

Figure 33. Contributions to the growth of GDP per capita originated in the growth of the female and male employment ratios

Several authors have indicated that the Mexican economy suffers from a rigid labor market, due to the excessive protection of employment, which gives rise to the growth of informality. It should be noted that female and male self-employment rates, which are indicators of informality, have persistently fallen in Mexico, as can be seen in Figure 34, even though labor regulations have not been subject to major revisions. This indicates that informality is not the result of labor market "rigidity"; it should be observed that the fall in informality was not enough to impart dynamism to labor productivity.

It should be added that in the 1950s, 1960s and 1970s the Mexican economy showed high growth rates, even though such "rigidity" existed even more strongly than at present. It should be borne in mind that "flexible" employment modalities, such as part-time employment and employment without established hours, cause serious mental health problems for workers who, as well, experience divorce, alcoholism, domestic violence, and pathologies that transmit to their daughters and sons (Brener, 1984; 2003). Therefore, if labor "rigidity" contributes to the well-being of the Mexican family, blessed be it. 


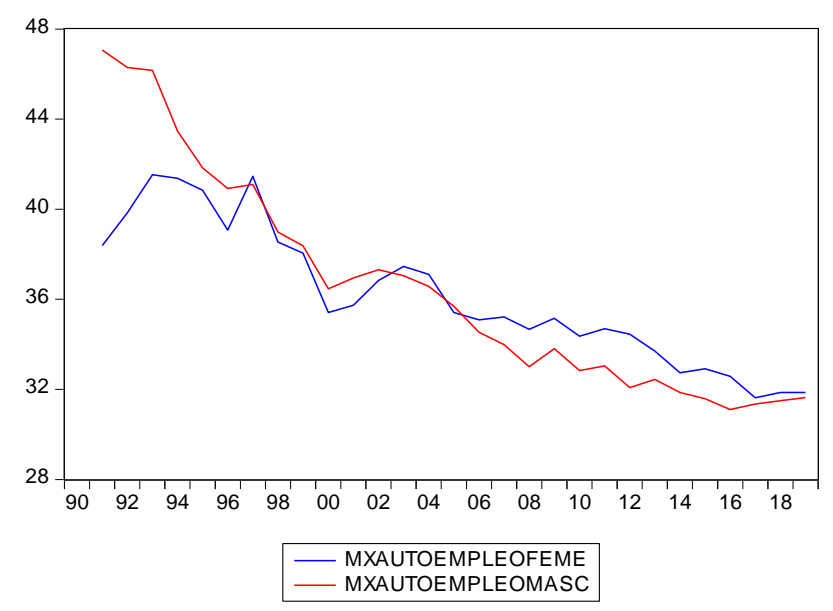

Figure 34. Rates of female and male self-employment

\section{Income distribution}

It is of interest to present comments on the changing structure of income distribution in the NAFTA countries, given that income distribution has been recognized as a variable that imparts dynamism to the economy and to private investment (Caceres, 2000).

Table 13 presents the percentages of national income received by the richest and poorest 10 per cent of the population. While the income distribution changes in the US and Canada are not high, Mexico has experienced noticeable improvements. The percentages of income received by the 10 per cent richest decreased from 43.1 to 36.4 between 1992 and 2018, while the percentage received by the poorest 10 per cent increased from 1.2 to 2.0 per cent; in that time the Gini coefficient decreased from 53.7 to 45.4. By Latin American standards these are remarkable achievements; there are only very few countries where the poorest 10 per cent receive at least 2 per cent of national income, or the richest receive less than 35 per cent (Note 4).

That improvements in income distribution did not improve economic growth in Mexico may be associated with its deindustrialization process; it may be the case that the middle class from resulting income distribution consumes imported products, that do not exert traction to the economy.

Table 13. Income distribution in countries members of NAFTA.

\begin{tabular}{|c|c|c|c|c|c|c|}
\hline \multirow[b]{2}{*}{ Year } & \multicolumn{2}{|c|}{ Mexico } & \multicolumn{2}{|c|}{ USA } & \multicolumn{2}{|c|}{ Canada } \\
\hline & $10 \%$ High & $10 \%$ Low & 10\% High & $10 \%$ Low & $10 \%$ High & $10 \%$ Low \\
\hline 1991 & & & 27.1 & 2.0 & 23.6 & 2.9 \\
\hline 1992 & 43.1 & 1.2 & & & & \\
\hline 2000 & 42.0 & 1.3 & 30.3 & 1.9 & 25.5 & 2.7 \\
\hline 2010 & 37.1 & 1.6 & 29.3 & 1.8 & 26.0 & 2.7 \\
\hline 2016 & & & 30.4 & 1.8 & & \\
\hline 2017 & & & & & 25.3 & 2.7 \\
\hline 2018 & 36.4 & 2.0 & & & & \\
\hline
\end{tabular}

\section{North American Social and Dignity Compact}

Given the tendencies towards economic stagnation and the adverse developments in the labor markets of the three NAFTA countries, it would be convenient that the member countries jointly structure, execute and monitor a North American Social and Dignity Compact that would include investments in areas known to be effective in overcoming economic stagnation tendencies and in granting workers better capabilities to enjoy a life characterized by dignity, and to compete in world markets. These areas are, among others, investments in early childhood education, in education quality, technical education, promotion of gender equality, and rural development. The aim would be to match NAFTA's significant increases in trade with equally significant increases in human development. These investments would "shield" workers from vicissitudes from the international economy and would contribute to the making of North America into an integrated social development area. The Pact should include provisions to direct special attention to the improvement of the 
well-being of the Native American population across the three countries, so that it has more and better opportunities to enjoy a life with dignity.

It has to be mentioned that there is evidence, (Caceres, 2017), that the strength of institutions, and particularly the rule of law, are endogenous to advances in social development, that is, solid institutions result from the clamor for change from a population that has achieved high levels of human capital; it is their human capital that enables citizens to structure and execute collective actions conducive to institutional strength, and to repudiate bad governments at the polls.

Given the evidence existing in Latin America of a positive association between public social spending and that governance indicators, the North American Social Compact should promote a commitment by the NAFTA countries to increase social spending. To stress this point Figures 35 and 36 show that Latin American countries' education quality indexes, measured as the scores obtained in reading and mathematics tests, (Terceromatematicas), (Sextolectura), conducted in 2013 by the regional office of UNESCO (Note 5), increase as the respective countries' public sector expenditure in education as a percentage of GDP (Gastoeducacion), increases (Note 6).

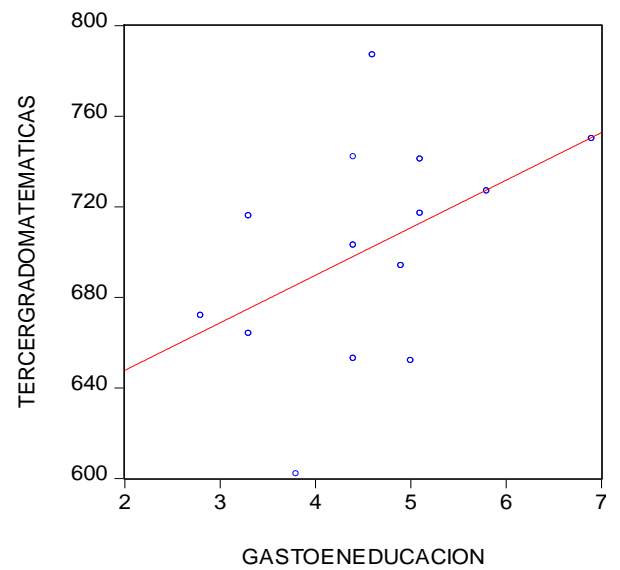

Figure 35. Education expenditure as percentage of GDP and third grade scores in mathematics in Latin American countries

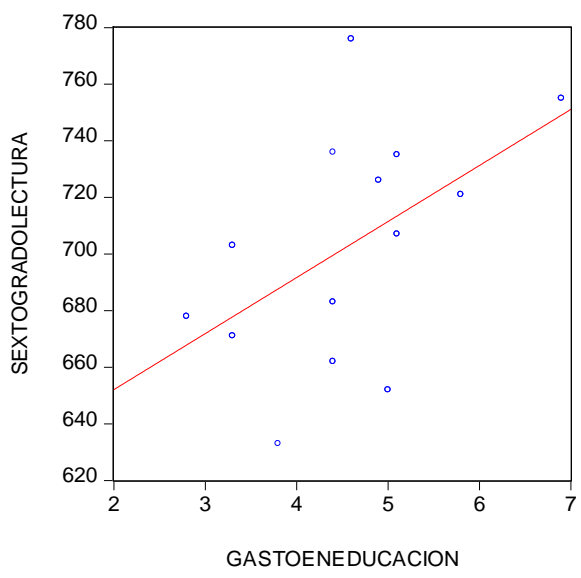

Figure 36. Education expenditure as percentage of GDP and sixth third grade scores in reading in Latin American countries.

The point to stress is that the Latin American countries' indexes of rule of law, (estadoderecho), taken from the World Bank's Governance Indicators, show positive relationships with the quality of education, (Figures 37 and 38 ), that is, with the reading and mathematics scores.

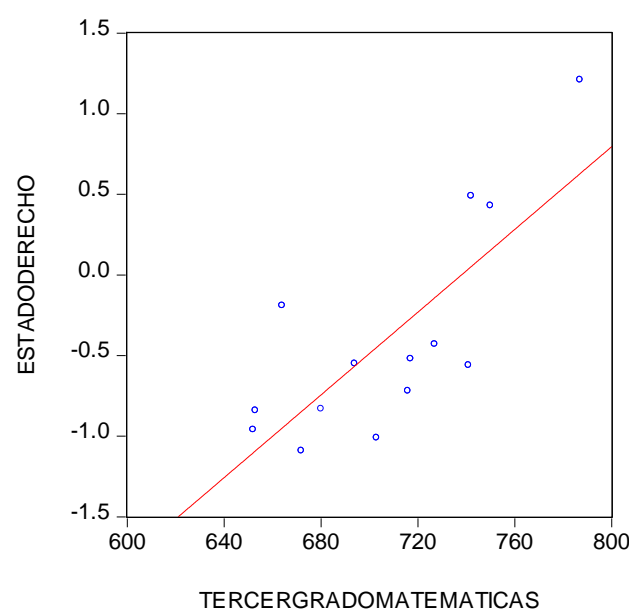

Figure 37. Third grade mathematics scores and index

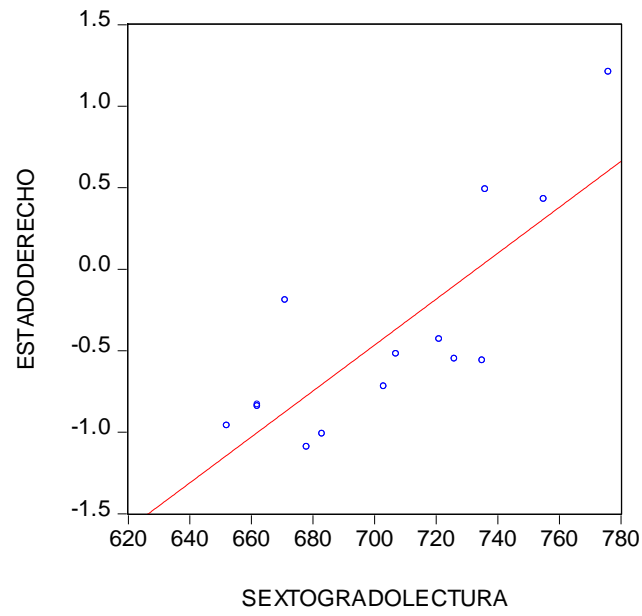

Figure 38. Sixth grade scores in Reading and index

Since these scores are determined by public spending in education as percentage of GDP, as seen on Figures 35 and 36, it can be deduced that education expenditures determine the rule of law in Latin America. 
This is the relationship shown on Figure 39, which indicates that the index of rule of law increases as the education expenditures as percentage of GDP increase.

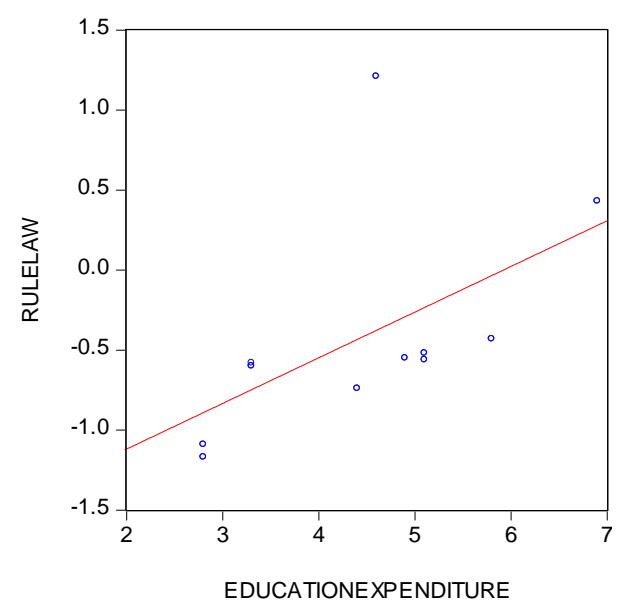

Figure 39. Education expenditures as percentage of GDP and index of rule of law in Latin American countries

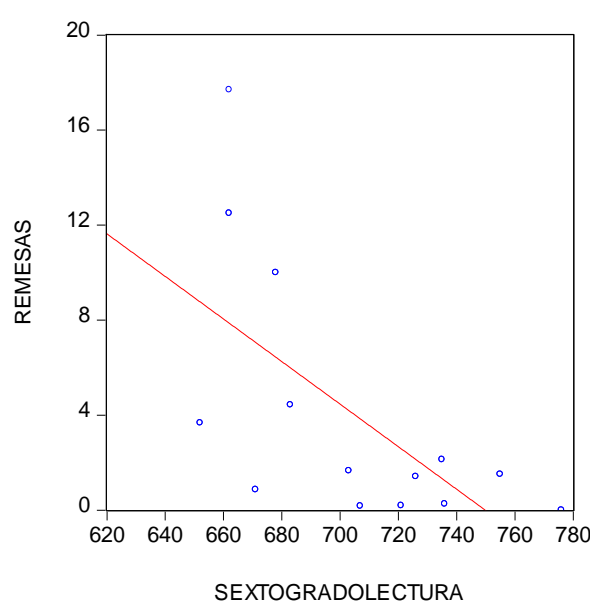

Figure 40. Remittances as percentage of GDP and reading scores in sixth grade

As well, remittances as percentage of GDP, which can be interpreted as an indicator of past emigration, shows a negative relation with quality of education represented by the reading scores in sixth grade, as shown in Figure 40 (Note 7):

An equation was estimated expressing the number of homicides per 100,000 persons in each country, corresponding to 2013, in terms of public expenditures in education as percentage of GDP and of a qualitative variable, Cuali20, that represents the countries where homicides per 100,000 inhabitants are above 20:

Homicides $=22.7003+20.9963$ Cuali20 -2.9415 Gastoeducacion

$\mathrm{R} 2=0.85$

This equation indicates that as public expenditure on education increase, the annual number of homicides per 100,000 tends to decrease. Thus, social expenditures is a "pacification" mechanism.

The previous Figure and equation indicate that increasing public sector expenditures in education would be conducive to increase education quality and governance, and to decrease emigration and violence.

\section{Conclusions}

The results of this paper indicated that the stagnation trend shown by the NAFTA member countries lies in deindustrialization, which in turn is explained by the reduction in import tariffs. Tariff reduction was already a process underway in the United States and Canada when the NAFTA Treaty came into effect, contrary to the case of Mexico, which still maintained adequate levels of protection, which fell dramatically after 1996. Thus, the United States and Canada cannot argue that their economic stagnation originates in NAFTA. The liberalization of trade in these two countries propitiated the growth of imports not only from Mexico but also from other countries. NAFTA has given rise to what could be called an integrated area of North American economic stagnation. Thus, the three countries should undertake policies to revert such tendencies, emphasizing investments in infrastructure, human capital and technology. and establishing protection measures and other incentives to encourage reindustrialization. NAFTA should be the means to multiply efforts to attain economic dynamism and high levels of social development, so as to convert the North American subcontinent into one characterized by prosperity, happiness and innovation.

One result of deindustrialization has been the loss of female jobs in the industrial sector in the three countries, with adverse consequences on domestic savings, investment, economic growth, and external solvency.

Within the framework of the tasks to recover economic dynamism, special importance must be given to increasing female employment. To achieve this purpose, public investment in childcare centers should receive a special boost, with a view to supporting women to enter the labor market and / or continue their studies. Evaluations of childcare programs in several Latin American countries show that one of their results is to increase the economic growth rate (World Bank, 2016). Nursery schools are also important given the declining 
trend in the ratio of female youth employment to population.

The actions to be undertaken within the framework of post-covid social programs, special importance should be given to emergency employment programs, with a view to offering employment and avoiding outbreaks of violence. It would be a sad irony if people who did not die from the attacks of the Covid found premature death due to their experiences of unemployment.

The results also show the importance of supporting reindustrialization. There is no single recipe on how to achieve this goal; a first step may be to examine the experiences of countries that have managed to recover the manufacturing sector, for example Japan, and deduce the "lessons learned" that these experiences offer. Some elements of an industrial policy in Mexico could be the negotiation with its NAFTA partners a clause that enables Mexican industry to impart greater added value to its maquila exports. Another element of Mexico's industrial policy may be to guarantee abundant credit to the private sector, a supply that has not been dynamic in the past, as well as the creation of special economic zones for processing agricultural products to be exported; the accelerated depreciation modality for private sector investments in export manufacturing; and human resources training.

Of special importance is the relationship between imports and investment that was shown in Figure 18, which shows that if the investment rate is conducive to achieve high productivity manufacturing production, imports will have a limited impact on the domestic market given the greater national capacity for efficient production.

This calls for the development of policies to increase investments in technology, in training of human resources, in physical infrastructure, which will provide the manufacturing sector with high productivity and a better capacity to compete with imported goods.

Likewise, Mexico should establish a strategy for its commercial, cultural and investment relations with China, with a view to increasing its exports to that country. China offers exports possibilities to Mexico that its NAFTA partners do not offer; China buys Mexican goods for which the United States and Canada have no demand, mainly agricultural and minerals.

It should be noted that Mexican investment in research and development is extremely low; its increase would be a decisive step in promoting innovation in the manufacturing sector. In this sense, it is appropriate to evaluate the current support system for start-ups with a view to promoting greater coverage in the national territory, and to establish priorities and a national monitoring system, as well as to search for partners abroad. For these purposes, the creation of the National Entrepreneurship Fund could be of value.

There is no definition or measurement applied to deindustrialization, the most common definitions refer to the falls in the share of the value added of the manufacturing sector in GDP, or of employment in the manufacturing sector as a percentage of total employment. An accurate measurement of deindustrialization can be achieved through the application of latent variables theory. This application would consist of the proposal of the causal variables that give rise to deindustrialization, such as the fall in tariffs, the falls in investment, credit and exports as a percentage of GDP. The outcome variables can be the falls in the value added of the manufacturing sector as a percentage of GDP, in female employment in the industrial sector, the fall in the ratio of female to male employment in said sector, and the fall in the economic growth rate. With this analysis, it would be possible to determine which are the variables that determine deindustrialization and what its effects are, while an estimate of the magnitude of deindustrialization in each year of the analysis period would be obtained.

Recent studies have proposed methodologies to determine the fragility of the economic growth of a given country ("growth at risk"), for which they estimate equations in which the economic growth rate is subject to the influence of variables that influence its trajectory, such as investment, exports, etc. The results of this paper show the negative repercussions that deindustrialization has on economic growth, so the analysis of the fragility of growth should include other variables, such as the value added of the manufacturing sector, as well as the ratio of employment to population, and labor productivity

Another analysis to know the nature of deindustrialization lies in the estimation of equations of discriminant analysis that express the percentage of the manufacturing sector in GDP in terms of variables that a priori are associated with deindustrialization, such as the tariff on imports, the rate investment, credit to the private sector, among others. The estimation of the discriminant function would allow to know the variables that are related to deindustrialization, that promote or prevent it, as well as the critical value of the discriminant function that determines the emergence of deindustrialization. A similar study can be conducted with logit analysis.

Given the importance of protecting the national manufacturing industry, special importance lies in investigating applications of behavioral economics with a view to determining the messages directed to the population to 
make national products more attractive than imported ones. This could consist of sending written messages to focus groups on the benefits that exist in the consumption of domestic products by virtue of the contribution they make to maintaining employment levels in the industrial and agricultural sectors, as well as to avoid family dislocations and eruptions. of violence. The messages could also refer to the importance of the country being self-sufficient in certain products that are essential for the well-being of the population, and for national security.

It could be argued that this measure violates the precepts of "free" trade, but this measure is legitimate and valid; it must be borne in mind that the existence of subsidies to producers and exporters, as well as the existence of economies of scale enjoyed by the countries from which developing countries import, mean that there is nothing "free" in international trade, and it is not necessary to sacrifice the employment of workers and the welfare of the family, to comply with zombie theories that represent the cruelest bad practice in economics.

It should be noted that the now developed countries, as well as the "Asian Tigers", did not achieve their economic takeoff based on economic liberalization; Stiglitz (2003) has shown that the developed countries that promote economic liberalization in the developing countries never implemented these measures in their economies. The pressure to liberalize international trade can be seen as a manifestation of greed and voracity prevailing in international power circles.

The results from Nafta and other developing countries that undertook trade liberalization programs lead to a very precise conclusion:

Fuck free trade.

It should be emphasized that the ratio of male employment to population in Mexico has persistently fallen, which has negative implications on economic dynamism. This is more accentuated in the case of the male youth population.

The fall in youth employment is associated with emigration flows to the United States, which highlights the cost of emigration for Mexican society. In addition to the development of campaigns urging youth not to emigrate, of special importance is the design and implementation of emergency employment programs, such as those in construction and repair of physical infrastructure, as well as programs to facilitate companies to hire young people. The same can be said of programs that facilitate the enrollment of young people in tertiary education levels, complemented by scholarships to cover the costs of tuition and food and lodging. It should be noted that a program for the construction of small infrastructure works carried out in El Salvador was effective in reducing irregular emigration and violence in the areas where the works were carried out, according to an evaluation by the World Bank (Acosta \& Monsalve, 2018).

Also with a view to combating emigration, reference should be made to the work of Hanson and Spillimbergo (1996) who showed that apprehensions of Mexican citizens trying to enter the United States increased as the difference between the real wages of both countries increased. Hence the importance of restoring the purchasing power of wages in Mexico in a timely manner.

The results showed that in Mexico, given the falls in male employment and labor productivity, female employment became the source of economic growth. To maintain this contribution of female employment, the construction of a national network of childcare centers is of particular importance, especially in light of the successful experiences of countries such as Canada. This will allow women, and especially single mothers, to enter the labor market or resume their studies, thus generating the consequent benefits of economic growth. It must be taken into account that in Mexico the percentage of women between 15 and 19 years old who have had or are expecting children is 18 percent, high in Latin America. In addition, the percentage of women between 15 and 24 years old who neither study nor work, the so-called NEETS, was 28 percent in 2018, one of the highest in Latin America. The situation of NEETS, which includes young women who have withdrawn from the labor market, possibly to dedicate themselves to caring for their children or people of old age, or because they have given up looking for a job, is conducive to a life of poverty; The evidence shows that only 16 percent of NEETSs rejoin the labor market (Cardenas, de Hoyos, \& Szekely, 2015). It is valid to state that NEETS who are mothers transmit their situation of poverty to their daughters and sons.

Another stream of literature has analyzed the case of the "middle income trap", which middle income countries experience when they incur stagnation tendencies. It is valid to state that this situation is due to the persistent gender employment gap that limits the mobilization of domestic savings and therefore investment and economic growth.

In the same sense, the results show that reciprocal trade in an area of economic integration will acquire dynamism as the member countries reduce the gender gaps. In other words, gender equality is an instrument for 
facilitating trade.

Therefore, the theory and practice of economic integration, in addition to the importance it attaches to the aspects of tariffs, and creation and diversion of trade, should pay special attention to closing the gender gaps, as a means of promoting trade flows in the integration area. Just as great attention has been paid to the coordination of economic policies within the framework of economic integration programs, mechanisms will also have to be established to facilitate the coordination of gender policies leading to the closing of employment and wage gaps, which would impart dynamism to the member countries of the integration scheme. It should be noted that Cuberes and Teignier (2016) estimated that in Mexico the elimination of the gender gap in labor participation would lead to an increase in GDP by 22 percent.

The declining trends in labor productivity and the ratio of male employment to population in Mexico must be considered. Regarding the first, it must be mentioned the importance of carrying out large investments in physical infrastructure that, in addition to increasing labor productivity, would provide private sector companies with greater capacity to compete with imports. Likewise, special importance lies in improving the quality of education and combating desertion from school.

At present a consensus prevails on the origin of the causes that determined the "miracles" of the "Asian Tigers", which is explained by the fact that these countries made the most important thing: massive investments in physical infrastructure and education. It should be noted that in Vietnam, the new "Tiger", the public investment rate reached 17 percent of GDP, more than six times that of Mexico, of 2.67 percent of GDP in 2019. These numbers explain why Mexico is not a "Tiger".

Give justice to the weak and the orphan;

Maintain the right of the lowly and the destitute.

Rescue the weak and the needy;

Deliver them from the hand of the wicked.

Psalm, 82, 3-4.

Do not plan harm against your neighbor who lives trustingly beside you.

Proverbs 3.29.

Trust in the Lord with all your heart.

Proverbs 3, 5.

For there is nothing hidden, except to be disclosed; nor is anything secret, except to come to light,

Mark, 4, 22.

References

Acosta, P., \& Emma, M. M. (2018). Public Works and Crime: Evidence from El Salvador. World Bank woking paper 8384 . https://doi.org/10.1596/1813-9450-8384

Arora, V., \& Ahanasios, V. (2004). How Much Do Trading Partners Matter for Growth? IMF working paper 04/26. https://doi.org/10.5089/9781451844412.001

Baspalova, O., \& Marina, R. (2019). Macrofinancial Linkages and Growth at Risk in the Dominican Republic. IMF working paper 19/246. https://doi.org/10.5089/9781513519203.001

Bluestone, B. (2008). Employment in Non-Farm Payrolls by Major Industrial Sectors. Department of Labor, Bureau of Labor Statistics.

Brener, M. H. (1984). Estimating the Effects of Economic Change on National Health and Social Well-being. Joint Economic Committee, US Congress, Washington DC.

Brener, M. H. (2003). Unemployment and Public Health in Countries of the European Union, European Commission. Director General for Employment and Industrial Relations and Social Affairs, Luxembourg.

Caceres, L. R. (2017). Deindustrialization and Economic Stagnation in El Salvador. Revista de la Cepal, 122. https://doi.org/10.18356/9c372d5b-es

Caceres, L. R. (2017). Financing Investment in Sub-Saharan Africa: Savings, Human Development, or Institutions? Journal of Developing Areas, 49, 1-23. https://doi.org/10.1353/jda.2015.0122

Caceres, L. R. (2018). Hechos Estilizados sobre la Calidad de la Educación en America Latina. unpublished. 
Caceres, L. R. (2020). Género y Ahorro Interno en America Latina. Revista Mexicana de Economía y Finanzas. https://doi.org/10.21919/remef.v15i3.515

Caceres, L. R. (2021a). Desindustrializacion en Mexico y Centroamerica. unpublished.

Caceres, L. R. (2021b). Gender, and Domestic and External Savings in Guatemala. International Journal of Economics and Finance. https://doi.org/10.5539/ijef.v13n6p165

Caceres, L. R. (2021c). Employment, Savings and Economic Growth in Honduras. unpublished.

Caceres, L. R. (2021d). Remittances, Regional Integration and Balance of Payments Constrained Growth in El Salvador. International Journal of Economics and Finance, 13, 50-63. https://doi.org/10.5539/ijef.v13n3p50

Cardenas, M., de Hoyos, R., \& Szekely, M. (2015). Out-of-School and Out-of-Work Youth in Latin America: A Persistent Problem in a Decade of Prosperity. Economica, 16.

Cuberes, D., \& Teignier, M. (2016). Aggregate Costs of Gender gaps in the Labor Market: A Quantiitative Estimate. Journal of Human capital, 10, 1-32. https://doi.org/10.1086/683847

Dasgupta, S., \& Ajit, S. (2006). Manufacturing, Services and Premature De-Industrialization in Developing Countries: A Kaldorian Empirical Analysis. Centre for Business Research, Cambridge, University of Cambridge, agosto. https://doi.org/10.1057/9780230801462_23

David, A., Goncalves, C., \& Werner, A. (2020). Reexaming the National Saving- Investment Nexus Across Time and Countries. IMF working paper. https://doi.org/10.5089/9781513548579.001

Dollar, D., \& Wolff, N. (1993). Competitiveness, Convergence, and International Specialization. Cambridge, Mass.:The MIT Press.

Dunsch, S. (2016). Okun's Law and Youth Unemployment in Germany and Poland. International Journal of Management and Economics, 49, 34-57. https://doi.org/10.1515/ijme-2016-0003

Feldstein, M., \& Horioka, C. (1980). Domestic Savings and International capital Flows. Economic Journal, 90(358), 314-329. https://doi.org/10.2307/2231790

Greenstein, J., \& Anderson, B. (2008). Premature Deindustrialization and the Defeminization of Labor.

Hanson, G. H., \& Antonio, S. (1996). Illegal Immigration, Border Enforcement and Relative Wages: Evidence from Apprehensions at the US-Mexico Border. Document de trabajo NBER. https://doi.org/10.3386/w5592

Kaldor, N. (1966). Causes of the Slow Rate of Economic Growth of the United Kingdom. Cambridge University Press.

Lawrence, R. Z. (1983). Is Trade Deindustrializing America? A Medium Term Perspective. Brookings Papers on Economic Activity, Washington DC, The Brookings Institution. https://doi.org/10.2307/2534354

Nickell, S. R., \& Joanna, S. (2008). The Uneven Pace of Deindustrialization in the OECD. The World Economy, 31. https://doi.org/10.1111/j.1467-9701.2008.01125.x

Phillips, P. C. B., \& Hansen, B. E. (1990). Statistical Inference in Instrumental Variables Regressions with I(1) Processes. Review of Economic Studies, 57. https://doi.org/10.2307/2297545

Rosen, H. (2008). Designing a National Strategy for Responding to Economic Dislocation, testimony before the House Science and Technology Subcommittee on investigation and oversight.

Rowthorn, R., \& Ramana, R. (1998). Growth, Trade and Deindustrialization. IMF working paper wp/98/60. Washington DC, International Monetary Fund. https://doi.org/10.2139/ssrn.882328

Saeger, S. S. (1997). Globalization and Deindustrialization: Myth and Reality in the OECD. Weltwirschaftliches Archiv, 133. https://doi.org/10.1007/BF02707404

Santos, P. A. (2002). The Effects of Trade Liberalization in Imports in Selected Countries. World Development, 30. https://doi.org/10.1016/S0305-750X(02)00014-1

Santos, P. A., \& Anthony, P. T. (2004). The Impact of Trade Liberalization on Export Growth, the Balance of Trade and the Balance of Payments in Developing Countries. The Economic Journal, 114. https://doi.org/10.1111/j.0013-0133.2004.00187.x

Scarpetta, S., Sonnet, A., \& Manfredi, T. (2010). Rising Youth Unemployment During the Crisis: How to Preventt Negative Long-Term Consequences on a Generation. OECD Social, Enployment and Migration Working Papers number 106. 
Seguino, S., \& Floro, M. S. (2013). Does Gender have any Effect on Aggregate Saving? International Review of Applied Economics, 17, 147-166. https://doi.org/10.1080/0269217032000064026

Steinberg, C., \& Masato, N. (2012). Can Women Save Japan? IMF working paper. https://doi.org/10.2139/ssrn.2169787

Stiglitz, J. (2003). El Rumbo de las Reformas: Hacia una Nueva Agenda para America Latina. Revista de la Cepal, 80. https://doi.org/10.18356/46a2a558-fr

TERCE. (2016). Tercer Estudio Regional Comparativo y Explicativo de la Calidad de Educación en America Latina. UNESCO.

Thirlwall, A. (1979). The Balance of Payments Constraint as an Explanation of International Growth Differences. Banca Nazionale del Lavoro Quarterly Review, 128.

Tregenna, F. (2016). Deindustrialization and Premature Deindustrialization. In J. R. Ghosh, R. Kattel, \& E. Reinert (Eds.), Elgar Handbook of Alternative Theories of Economic Development. https://doi.org/10.4337/9781782544685.00046

Tsounta, E. (2006). Why are Women Working so Much More in Canada? An International Perspective. IMF working paper 06/92. https://doi.org/10.5089/9781451863529.001

World Bank. (2016). Gender Strategy.

\section{Notes}

Note 1. In this and other equations the " $\mathrm{t}$ " statistics are shown underneath the respective coefficients.

Note 2. Rosen adds: "But job loss does not affect individuals only, although it touches many who, having dedicated their lives and sometimes their health to employers, now feel betrayed and economically expendable. As a laid off Johnson Controls worker in Louisville, Ky., explained: "I have always been a hard worker... You go in there and give a guy a day's work for a day's pay". But, he lamented, the company didn't see it that way: "I gave them 110 percent. They paid me 110 per cent but they did everybody out there wrong. Another laid off worker suggested that US companies were "letting the people of America down", and this would "eventually come back to them".

Note 3. David, Goncalves, and Werner (2020) present a recent analysis of this paradox.

Note 4. In 2018, countries where the poorest 10 per cent received at least 2 per cent of national income are, besides Mexico: Nicaragua, 2.0\%, Uruguay, 2.2\%, El Salvador 2.3\%. Countries where richest 10 per cent received less than 35 per cent of national income are: Ecuador, 34.3\%, Dominican Republic, 35\%, Bolivia, $32.1 \%$, Uruguay, 297\%, and El Salvador, 29.7\%.

Note 5. The reading and mathematics scores of 15 Latin American countries, are taken from TERCE (2016). IN that TERCE testing, Honduras, Nicaragua and Guatemala had the lowest scores of all Latin American countries.

Note 6. Graphs are taken from Caceres (2018).

Note 7. Graphs 35, 36, 37, 38, 39 and 40 were prepared with 2013 data.

\section{Copyrights}

Copyright for this article is retained by the author(s), with first publication rights granted to the journal.

This is an open-access article distributed under the terms and conditions of the Creative Commons Attribution license (http://creativecommons.org/licenses/by/4.0/). 